\title{
Manx Traditional Songs, Rhymes and Chants in the Repertoire of the Last Native Manx Speakers
}

\author{
GEORGE BRODERICK \\ University of Mannheim
}

In the course of taking down/sound-recording material from the last native Manx speakers between 1883 and 1972 a number of lyrical texts formed part of some of the collections. A number of such texts have already appeared in print, others appear here for the first time. This article seeks to bring all such known texts together under one roof in order to serve the interests of various fields of study concerned with traditional lyric-text material.

Keywords: Native Manx speakers; songs; rhymes; chants; end-phase of Manx

\section{Introduction}

The purpose of this article is to present the raw material of the songs, rhymes and chants found in and recorded from Manx tradition from the last native Manx speakers between 1883 and 1972 and to make it available to scholars as a resource.

Manx Gaelic is one of the Insular Celtic languages that in recent times experienced language obsolescence, and has thereby attracted interest from scholars at an early date in the recent history of language and linguistic research. Leaving aside the early linguistic enquiries of Edward Lhuyd (1703-1704; Lhuyd 1707) and Prince Louis-Lucien Bonaparte (c.1856; Bonaparte 1884) into aspects of Insular Celtic (including Manx), solely in Manx terms the first known early scholastic enquiry into Manx took place in 1883 when Prof. John Strachan, University of Manchester, and Father Richard Henebry of Co. Waterford, Ireland, visited Man to take down in phonetic script the text of the traditional Manx love-song Ec ny Fiddleryn 'at the fiddlers' (\$2.9) from a Manx tradition-bearer, fisherman Thomas Kermode (1826-1901), Bradda, Rushen (Strachan 1897). The fact that the first known scientific enquiry into Manx in modern times involved the collection of a Manx Gaelic folksong is significant in that it makes clear that the folksong was central to Manx tradition. ${ }^{1}$ Three years later this was followed by the systematic enquiry made 1886-1893 by Prof. John Rhŷs, University of Oxford, into Manx phonology

1 Probably also central to Gaelic tradition are the song-texts, both complete and fragmentary, collected along with prose pieces and printed in the following Irish and Scottish Gaelic dialect surveys: Irish: Rathlin Island, Co. Antrim (Holmer 1942), Teelin, Co. Donegal (Wagner 1959), Tyrone Irish (Stockman \& Wagner 1965), Erris, Co. Mayo (Mhac an Fhailigh 1968), Tourmakeady, Co. Mayo (de Búrca 1970), Iorras Aithneach, Co. Galway (Ó Curnáin 2007), Scottish Gaelic: Leurbost, Isle of Lewis (Oftedal 1956), Arran (Holmer 1957), Kintyre (Holmer 1962). 
comprising also a number of traditional song-fragments (Rhŷs 1895; Broderick 2018b). In addition, this can be seen in material collected later by Dr. Rudolf Trebitsch 1909; Lechleitner \& Remmer 2003; Prof. Carl Marstrander 1929-1933 (HLSM/I: Texts); Prof. Kenneth Jackson 1950/1951 (Jackson 1955; HLSM/I: Texts); Clement: 1972 (HLSM/I: Texts). In addition, sound-recordings were also made by the Irish Folklore Commission during April/May 1948 and Yn Çheshaght Ghailckagh ('The Manx Language Society') 1951-1953 (HLSM/I: Texts). Details of the song contents collected by the foregoing individuals and bodies are listed below (\$1.2).

\section{I.I The collected material}

As noted above, the following collection of Manx traditional songs and songfragments derives from a series of scientific surveys on obsolescence in Manx Gaelic from native Manx speakers undertaken in Man between the years 1886 and 1972. These surveys involved the gathering of linguistic material, whether through phonetic notation of textual readings and questioning, formal questionnaires and/or sound-recordings, in order to enable a phonological and morphological assessment of the state of Manx Gaelic at the time. Such material also included connected prose-texts in the form of stories and anecdotes, as well as lyric-texts consisting exclusively of traditional songs, rhymes, chants, etc., either complete or in fragmentary form.

A similar undertaking was made in Ireland in 1931 by the German soundarchivist Wilhelm Albert Doegen (1877-1967) ${ }^{2}$ whereby stories and traditional songs were sound-recorded from some forty-one informants from all parts of the historical province of Ulster. ${ }^{3}$ For details, see Ní Bhaoill (2010). The Manx scene as discussed here would belong to that genre.

The prose-texts and some of the lyric-texts were published in HLSM/I: Texts, both in phonetic script and in the standard Manx orthography of the Manx Bible, with English translation. In addition, many surviving song-texts from various manuscript collections, either in standard or (often) non-standard Manx orthography, have also seen the light of day (Broderick 1980 to date). The songtexts gathered here from the last native Manx speakers are brought together for the first time to enable a concise overview.

The whole is to be set in the cultural background of Manx traditional songs and music collected during the same period, essentially during the 1890s and first decade of the twentieth century, from collectors such as:

2 For a chronology of Doegen's life and times, see Simon et al. 2006.

3 From Lughbhadh, Árd Mhacha, Aontruim, Doire, Tír Eoghain, Inis Eoghain, Fánaid, Ros Guill, Cloch Cheannfhaolaidh, Gaoth Dobhair, Na Rosa, Tí Chonaill, An Cabhán, Liatroim (< http://www.smo.uhi.ac.uk/ oduibhin/doegen/index.htm $>$ ). 
1. Dr. John Clague (1842-1908), a medical practitioner of Castletown, Isle of Man (also a colleague of Prof. John Rhŷs (1840-1915) during the latter's visits to Man 1886-1893). For details, see Gilchrist (1924-1926); Miller (2015: Manx Notes nos. 198-206). ${ }^{4}$

2. The Gill Brothers: William Henry Gill (1839-1923) and the Deemster ${ }^{5}$ John Frederick Gill (1842-1899). For details, see Miller (2006: Manx Notes 51-64).

3. Arthur William Moore, SHK (1853-1909). For details, see Miller 2017, 2019 .

4. George Frederick Clucas (1870-1937). For details, see Broderick 19811982.

5. Sophia Morrison (1859-1917) \& Josephine Kermode (1852-1937). For details, see Broderick forthcoming a.

6. Mona Douglas (1898-1987). Mona Douglas Collection of Manx music and songs. In private hands. For details, see Broderick 2008.

\section{I.2 The collectors}

Such song-texts were obtained from the various surveys and sound-recordings which took place in the following years 1883-1972:

LYRIC-TITLE

INFORMANT

LYRIC-TYPE

1883: Prof. John Strachan, University of Manchester, \& Father Richard Henebry, Co. Waterford (Strachan 1897).

\begin{tabular}{|l|l|l|}
\hline Ec ny Fiddleryn & Tom Kermode, Bradda, Rushen & Song complete text \\
\hline
\end{tabular}

1886-1893: Rhŷs: University of Oxford (Prof. John Rhŷs I886-1893). ${ }^{6}$

\begin{tabular}{|l|l|l|}
\hline Kiark Katreeney Marroo & Capt. Henry Watterson, MHK, Colby, Arbory & Chant complete \\
\hline Kiark Katreeney Marroo & Edward Faragher, Sr., Cregneash, Rushen & Chant complete \\
\hline Arrane Oie Vie & Margaret Cowle, The Rheast, Bride & Song-fragment \\
\hline Hop dy Naa & William Killip, Clyeen, Michael & Chant-fragment \\
\hline Hop dy Naa & John Kermode, Surby, Rushen & Chant-fragment \\
\hline Hop dy Naa & William Corrin, Cronk y Doonee, Rushen & Chant-fragment \\
\hline Hop dy Naa & 'Paaie Vooar' Margaret Taylor, Surby, Rushen & Chant-fragment \\
\hline Ny Kirree fo Niaghtey & Thomas Vondy, Ramsey (of Lezayre) & Song-fragment \\
\hline Ny Kirree fo Niaghtey & John Skillicorn, Ballagare, Lonan & Song-fragment \\
\hline Ny Kirree fo Niaghtey & Margaret Caine, Ramsey (of Maughold) & Song-fragment \\
\hline Yn Maarliagh Mooar & Margaret Caine, Ramsey (of Maughold) & Song-fragment \\
\hline Hudgeon y Fidder & John Carrine, Chasm House, Rushen & Song-fragment \\
\hline Hudgeon y Fidder & William Collister (abode unknown) & Song-fragment \\
\hline
\end{tabular}

$4 \quad$ Miller's Manx Notes references can all be found under Miller 2019.

5 Manx high court judge - GB.

6 For full details, see Broderick 2015, 2018b. 
1909: Vienna Recordings': Kaiserliche (later Österreichische) Akademie der Wissenschaften, Vienna (Dr. Rudolf Trebitsch, 5-8 August 1909) (HLSM/I: Texts). ${ }^{8}$

\begin{tabular}{|l|l|l|}
\hline Goll dy schoill & William Cowley, Douglas (of Lezayre) & Children's rhyme \\
\hline Myr s'liauyr yn oie geuree & William Cowley, Douglas (of Lezayre) & Song-fragment \\
\hline Ny Kirree fo Niaghtey & John Nelson, Ramsey & Song-fragment \\
\hline Yn Foldey Gastey & John Nelson, Ramsey & Song-fragment \\
\hline
\end{tabular}

1 929-1 933: Marstrander: University of Oslo, Norway (Prof. Carl J. S. Marstrander, 1929, 1930, 1933) (HLSM/I: Texts).9

\begin{tabular}{|l|l|l|}
\hline Abraham Juan & Thomas Taggart, Grenaby, Malew & Song-fragment \\
\hline Arrane er Inneenyn Eirinee & John Cain, Ballamoar, Jurby & Song-fragment \\
\hline Arrane ny Baatyn-eeastee & Joseph Woodworth, Port Erin, Rushen & Song-fragment \\
\hline Arrane ny Baatyn-skaddan & Edward Kennah, Ronague, Arbory & Song-fragment \\
\hline Arrane Oie Vie & Joseph Woodworth, Port Erin, Rushen & Song-fragment \\
\hline Arrane Oie Vie & Thomas Taggart, Grenaby, Malew & Song-fragment \\
\hline Arrane Oie Vie & Thomas Christian, Ramsey (of Maughold) & Song-fragment \\
\hline Colbagh Breck er Sthrap & John Cain, Ballamoar, Jurby & Song-fragment \\
\hline Cre'n Sorch dy 'Wreck' & James Kewley, Maughold & Song-fragment \\
\hline Graih my Chree & Harry Kelly, Cregneash, Rushen & Song-fragment \\
\hline Gubbylyn & Thomas Crebbin, Bradda, Rushen & Song-fragment \\
\hline Hie son Skylley Breeshey & John Cain, Ballamoar, Jurby & Song-fragment \\
\hline Kiare roie, kiare ny hoie & Thomas Christian, Ramsey (of Maughold) & Children's rhyme \\
\hline Mannin Veg Veen & Thomas Christian, Ramsey (of Maughold) & Song-fragment \\
\hline Mylecharaine & Thomas Taggart, Grenaby, Malew & Song-fragment \\
\hline Mylecharaine & Joseph Woodworth, Port Erin, Rushen & Song-fragment \\
\hline Nane, jees Mylechreest & John Cain, Ballamoar, Jurby & Children's rhyme \\
\hline Ny Kirree fo Niaghtey & Harry Kelly, Cregneash, Rushen & Song-fragment \\
\hline Oh, soieym seose syn uinnag & Harry Kelly, Cregneash, Rushen & Song-fragment \\
\hline Ooill as taarnagh & Thomas Christian, Ramsey (of Maughold) & Curse formula \\
\hline Freeinaghyn as Snaidyn & Thomas Crebbin, Bradda, Rushen & Children's rhyme \\
\hline Pipe as Tombagey & Thomas Christian, Ramsey (of Maughold) & Children's rhyme \\
\hline Shannon Rea & Harry Kelly, Cregneash, Rushen & Song-fragment \\
\hline Shee as fea & Harry Kelly, Cregneash, Rushen & Rhyme \\
\hline The 'Manx Fairy' (steamboat) & John Cain, Ballamoar, Jurby & Rhyme \\
\hline The 'Manx Fairy' (steamboat) & Thomas Christian, Ramsey (of Maughold) & Rhyme \\
\hline
\end{tabular}

7 Early sound-recordings of native Manx speech and Manx traditional songs, etc., made c. 1905-1909 (possibly till 1913) by Yn Çheshaght Ghailckagh ('The Manx Language Society'), are not included here, as (except for four cylinders containing Bible readings) they have seemingly not survived. According to the report of the Annual General Meeting (1905) of Yn Çheshaght Ghailckagh, the following Manx traditional songs/ chants had evidently been phonograph recorded: Ec ny Fiddleryn, Hop-dy-Naa, Ny Kirree fo Niaghtey, Mylech[a]raine. For details, see Miller 2014: 1-9.

8 References to the Texts are to be found in HLSM/III: 159-169.

9 For details of Marstrander's Manx itinerary and his field-notes, see Broderick: 2018a. 


\begin{tabular}{|l|l|l|}
\hline Tom Jack John & Edward Kennah, Ronague, Arbory & Song-fragment \\
\hline Tom Jack John & Thomas Taggart, Grenaby, Malew & Song-fragment \\
\hline Tra ta dooinney skee & Thomas Christian, Ramsey (of Maughold) & Song-fragment \\
\hline V'a yn dow buirroogh & Thomas Christian, Ramsey (of Maughold) & Children's rhyme \\
\hline Ve dooinney veih Balnahowin & Thomas Christian, Ramsey (of Maughold) & Rhyme \\
\hline Vermayd Caabyl dys yn Anker & Harry Kelly, Cregneash, Rushen & Song-fragment \\
\hline
\end{tabular}

\section{8: Irish Folklore Commission Recordings, Dublin (22 April-5 May 1948)} (HLSM/I: Texts).

\begin{tabular}{|l|l|l|}
\hline Arrane ny Baatyn-eeastee & Ned Maddrell, Glenchass, Rushen & Song-fragment \\
\hline Brig Lily & Ned Maddrell, Glenchass, Rushen & Song-fragment \\
\hline Colbagh Breck er Sthrap & Annie Kneale, Ballagarrett, Bride & Song-fragment \\
\hline Juan Gawne & Annie Kneale, Ballagarrett, Bride & Children's rhyme \\
\hline Lhigey, Ihargey & Ned Maddrell, Glenchass, Rushen & Children's rhyme \\
\hline Shooyll, shooyll & Ned Maddrell, Glenchass, Rushen & Children's rhyme \\
\hline
\end{tabular}

1950-1 95 I: Jackson: University of Edinburgh (Prof. Kenneth H. Jackson, Christmas/New Year I 950/I95 I) (Jackson 1955: I 35-136, HLSM/I: Texts).

\begin{tabular}{|l|l|l|}
\hline Graih my Chree & Tommy Leece, Kerroomooar, Malew & Song-fragment \\
\hline Tom Jack John & Tommy Leece, Kerroomooar, Malew & Song-fragment \\
\hline
\end{tabular}

I 95 I- | 953: Yn Çheshaght Ghailckagh Recordings, Isle of Man (Late I 95 I-Mid 1953) (HLSM/I: Texts).

\begin{tabular}{|l|l|l|}
\hline Arrane ny Baatyn-eeastee & Ned Maddrell, Glenchass, Rushen & Song-fragment \\
\hline Brig Lily & Ned Maddrell, Glenchass, Rushen & Song-fragment \\
\hline Graih my Chree & Tommy Leece, Kerroomooar, Malew & Song-fragment \\
\hline Row oo ec y margey & John Kneen, Ballaugh Curragh (of Andreas) & Children's rhyme \\
\hline Row shiu ec y vargey & Ned Maddrell, Glenchass, Rushen & Children's rhyme \\
\hline Tom Jack John & Sage Kinvig, Garey Hollen, Arbory & Song-fragment \\
\hline Yn Graihder Jouylagh & Sage Kinvig, Garey Hollen, Arbory & Song-fragment \\
\hline
\end{tabular}

1972: Linguistic Survey of Scotland Recordings (David Clement 1972) (HLSM/l: Texts).

\begin{tabular}{|l|l|l|}
\hline A Quaaltagh Greeting & Ned Maddrell, Glenchass, Rushen & Custom rhyme \\
\hline Arrane ny Baatyn-eeastee & Ned Maddrell, Glenchass, Rushen & Song-fragment \\
\hline
\end{tabular}

\section{I.3 The texts}

The body of songs and song-fragments presented here is restricted to those that were recorded either in phonetic script or sound-recorded (the latter provided also in phonetic script in transcription). That is to say, only the song material that reveals how the various texts were pronounced are presented here. Though it will be seen that many of the song-texts exist only in fragmentary form, this does not necessarily mean that the informant could not have given more. The reasons for this may be multiple: for example, the formal circumstances of the recordings, simply forgetting the texts over time, or not fully learning the texts in the first 
place, etc. ${ }^{10}$ Nevertheless, the material available to us today is in my view sufficient to give us a good idea of what the informants could offer.

\section{I.4 The categories}

The thirty-eight Manx traditional songs and song-fragments presented here can be categorised according to type as follows:

Songs and chants to do with custom and tradition:

Songs: Arrane Oie Vie, Chants: Hop-dy-Naa, Kiark Katreeney Marroo, (N)Ollick Gennal.

Children's Rhymes:

Freeinaghyn as Snaidyn; Goll dy Schoill; Juan Gawne; Lhigey, Lhargey; Nane Jees, Mylechreest; Pipe as Tombagey; Row oo ec y Vargey; Shooyll, Shooyll yn Dooinney Boght; Va yn Dow Buirroogh.

Other rhymes:

Gubbylyn, The 'Manx Fairy', Shee as Fea, V'eh Dooinney veih Ballahowin.

Didactic songs:

Arrane er Inneenyn-Eirinee, Yn Maarliagh Mooar.

Love songs:

Abram Juan, Colbagh Breck er Sthrap, Ec ny Fiddleryn, Graih my Chree, Myr S'liauyr yn Oie Geuree, Oh, Soieym Seose syn Uinnag, Shannon Rea, Yn Graihder Jouylagh.

Narrative songs:

Mannin Veg Veen, Mylecharaine, Ny Kirree fo Niaghtey, Vermayd Caabyl dys yn Anker.

Satirical songs:

Cre'n Sorch dy 'Wreck', Hi son Skylley Breeshey, Tom Jack John, Hudgeon y Fidder.

10 A number of song-texts had tunes associated with them. These can be found in various song/music collections noted in $\S 1.1$ or in the List of References. Material appearing in the aforementioned collections (1883-1972) is not accompanied by any tunes at all, whether any texts were sung to tunes at the time of collection cannot be excluded but is unknown. 
Songs of loss and shipwreck:

Arrane mysh Coayl ny Baatyn-Eeastee, Arrane mysh Coayl ny Baatyn-Scaddan, Brig Lily.

\section{I.5 Earlier traditional Manx songs}

As can be seen, most of the song-texts are relatively recent, i.e. of nineteenthcentury provenance, e.g. the children's rhymes, Yn Graihder Jouylagh (c. 1860). Some songs, however, derive from at least the eighteenth century, if not earlier. They include: Arrane Oie Vie, Hop-dy-Naa, Kiark Katreeney Marroo, (N)Ollick Gennal, Shannon Rea (1792), Mylecharaine (ms. c. 1770), Ny Kirree fo Niaghtey (c. 1700), Hi son Skylley Breeshey (ms. c. 1770), Arrane mysh Coayl ny Baatynscaddan (1787, time of composition shortly after). Of the foregoing, the two songs that have constantly appeared in Manx publications down through the years and which are firmly associated with the Isle of Man are Mylecharaine and Ny Kirree for Niaghtey, and it is therefore not surprising that the latter, for instance, was often recorded, though interestingly enough neither of the two from any of the last native Manx speakers after Marstrander.

\section{I.6 Songs absent from the repertoire of the last native Manx speakers}

What is also perhaps of interest are song-texts that are absent, e.g. Fin as Oshin ${ }^{11}$ (ms. c. 1770, an example of a Gaelic Heroic Tale surviving in Manx tradition, possibly falling out of that tradition in the early years of the nineteenth century); Baase Illiam Dhone, ${ }^{12}$ a lament on the execution of Manx patriot Illiam Dhone (brown-haired William) -William Christian (1608-2 January 1662 or 1663)—of c. 1663 , used at least until the 1780 s, if not later, as a propaganda song against the Manx establishment; Berrey Dhone (1820 but likely of earlier provenance, possibly a Manx version of the Irish Caillech Bérri?). ${ }^{13}$ Also action-songs such as Thurot as Elliot $^{14}$ (1760, song partly written at the time, but seemingly enlarged after 1846) and Marrinys yn Tiger $^{15}$ (1778 and popular till c. 1830) have evidently fallen out of the repertoire. In addition, of the sixty-three or so broadside ballads in English (but of English, Scottish or Irish provenance) discussed in Speers (2016), only two seem to have survived in the last throes of the Manx song tradition: Shannon Rea ( $<$ Ireland?) and Yn Graihder Jouylagh ( $<$ Scotland?).

Nonetheless, the span of the subject-matter, as can be seen, is equally as broad as those collected by Moore during the 1890s, though it becomes clear that the song

11 cf. Broderick (2018d: 63-81).

12 cf. Broderick (1982b: 105-123).

13 cf. Broderick (1984a: 193-210).

14 cf. Moore (1896: xviii, third fn.).

15 cf. Moore (1896: xxvi-xxvii). 
repertoire among the last native Manx Gaelic speakers (as from 1883 onwards for our purposes here) begins to diminish over time. It is noticeable that such popular songs as Ny Kirree fo Niaghtey and Mylecharaine, as noted above, are not to be found among the last fifteen native Manx speakers, recorded between 1947 and 1972.

\section{I.7 Editorial technique}

In presenting the material below I have adhered to the following schema:

1. The phonetic rendition of the texts is set out in accordance with IPA principles. Parallel to this is the equivalent in the Standard Manx Orthography of the Manx Bible. This is followed by an English translation of the text, stanza by stanza, set in square brackets.

2. The titles of each text are given in capitals, followed, if in Manx, by an English translation in round brackets, then by the lyric type (whether song, chant, children's rhyme, etc.) also in round brackets. All form the title of the text.

3. In the following lines there then follow details of other textual versions, if any, of the text under discussion, whether in manuscript, in print, or in oral renderings, etc. These are then followed by details of any tunes associated with the text. The final section, if any, supplies details of the contents of the text in question. All or part of the foregoing may be accompanied by appropriate comment, either from myself or others.

4. So far as is known, thirty-eight separate lyric items were collected from native Manx Gaelic speakers between the years 1883 and 1972. The collected versions of each separate lyric item are then set out in chronological order, with name and abode of the informant, followed by the date of collection and reference to the source.

5. To finish, a discussion as to how the songs were sung is presented. This is then followed by a short conclusion.

\section{The songs, rhymes and chants in the repertoire of the last native Manx speakers (1883-1972)}

\section{I ABRAM JUAN (Abraham Juan) (song frag.)}

Text: Manuscript: Clague (Bk. 5: 60-61, Bk. 10: 128v, Bk. 16: 41). A manuscript version of four stanzas is recorded in Bk. 5 (MTSSF/II: 3-5) and eight stanzas in MNHL MD900 MS 08307 (c. 1830-1840).

Tune: Clague (Bk. 2/18: 2, Bk. 2/19: 1). Includes first stanza. Informant not recorded. The tune requires the last two lines of each stanza to be sung twice. 
Gilchrist (1924-1926: 173-174) prints the tune under the title Piyr dy Lauenyn Baney (a pair of white gloves) and adds:

The tune is a variant of the old dance-tune 'The Hempdresser' to which Burns wrote his song 'The De'il awa' wi' th' Exciseman'. On this account I have placed the tune and verse under dance-tunes. The verse may be nothing more than a dance-rhyme. At any rate it looks like one (Gilchrist 1924-1926: 174).

The song is bawdy in content.

ABRAM JUAN (song frag.).

Thomas Taggart (1846-1933), Grenaby, Malew, 27 August 1930 (M/IV: ${ }^{16} 2482-$ 2483; HLSM/I: 390-391).

I

kwai te 'krenkal $\varepsilon$ k mə yərəs

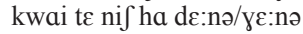

fe: mo hin 'to:n du:rt $\varepsilon$ :bram dzo:n

$l^{\prime} \varepsilon \int$ paiər $^{\mathrm{r}}$ də 'le:uðərən (sic) 'be:nə

II

๑: 'lep əð 'so:s as göu ro:d 'ta:i

du:rt ən vedn veg ' $\varepsilon: l ə n$ '

๑: 'be:r l'em 've mört 'hin də la:i

du:rt ' $\varepsilon$ :bram dzə:n ə se:uðə

III

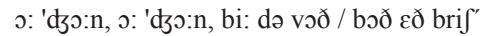
du:rt ə 'vedn veg 'E:lən'

kur 'bo:nda 'er as 'köure 'e:

du:rt 'e:bram 'ḑə:n ə 's $\varepsilon: u \int \partial$
Quoi ta crankal ec my ghorrys

Quoi ta nish cha daaney/ghaaney

She mee hene t'ayn dooyrt Abram Juan

lesh piyr dy lauenyn baney

Oh, lhap ad seose as gow royd thie

dooyrt yn ven veg aalin

Oh, b'are lhiam ve mayrt hene dy lhie

dooyrt Abram Juan y Saushey

[1. Who is knocking at my door / Who is now so bold / It is myself, said Abram Juan / with a pair of white gloves.

2. Oh, fold them up and go your way home / said the fine wee ${ }^{17}$ girl / Oh, I would prefer to lie with you / said Abram Juan y Saushey. ${ }^{18}$

3. O Juan, O Juan, your penis will then be broken / said the fine wee girl / Put a bandage on it and it will get better / said Abram Juan y Saushey].

16 M/IV refers to Vol. 4 of Marstrander's Manx manuscripts + page number(s). For full details of these mss., see Broderick: 2018a.

17 This 'Scottishism' is used here deliberately, as to my mind it translates Mx beg 'little' (G beag) more appropriately.

18 y Saushey possibly a nickname? Otherwise obscure. 


\subsection{ARRANE ER INNEENYN-EIRINEE (a song on farmers' daughters) (song frag.)}

Text: Ent. Toot dy innee[n] (fool of a girl) (MTSSF/I: 22-26). Broadside MNHL MS J2X among unacc. mss. for Harrison (1873; 25st.) with Eng. trans. by John Quirk, Carnygreie PA, dated Foxdale 06/02/1872; 25st. in Harrison (1873: 95-98); Moore (1896: 189-191 from Harrison 1873), R. Kerruish, Maughold, 25st. ent. Inneenyn Eirinee (farmers' daughters), MTSSF/I: 22-26. The stanza given here is no. 11 in Moore. Song composed by Juan Lewin, Sumner of Jurby, but seemingly modelled on an English original (Speers 2016: 61-62).

Tune: Clague C4/23:5 Thos Crellin, Peel; Moore (1896: 232 Thomas Crellin, Peel); i.e. the first variant of Carval ny Drogh-Vraane (Carval ${ }^{19}$ about the bad women) (Gilchrist 1924-1926: 248-249); viz. C1/6: 1 ent. Carval ny drogh Vraane, nn. [but R. Shimmin, Ballasalla Bridge ML], C3/39:1 ent. Drogh Vraane nn., as well as a version in English about the Manx patriot Illiam Dhone (William Christian 1608-1662/1663) (Gill 1896: 112-114). According to Gilchrist (1924-1926: 253), the first version has considerable resemblance to the Scottish air 'John Anderson, my jo'. For a discussion of this carval, see Gilchrist (1924-1926: 250-253).

The song, didactic in tone, takes the form of a tirade against the vanity and extravagance of the young women of the period (Gilchrist 1924-1926: 253).

ARRANE ER INNEENYN-EIRINEE (song frag.).

John Cain (1850-1939), Ballamoar, Jurby, 2 February 1933 (M/IV: 2632; HLSM/I: 312-313).

pu:s mi ə gre:i ho:r rød na ren rju dzenu mai pu:s mi tut $ə$ n'i:n' vu:r $^{\mathrm{r}} \varepsilon$ :rin'ax ă röu slei ek komal ta:i
Poose mee er graih hoghyr red nagh ren rieau jannoo mie Poose mee toot dy 'neen vooar eirinagh cha row y sleih eck cummal thie

[I married for the love of a dowry / a thing that never did any good / I married a fool of a farmer's daughter / her people could not keep house].

\subsection{ARRANE MYSH COAYL NY BAATYN-EEASTEE (a song about the loss of the fishing boats) (song frag.)}

Text: manuscript: Clague Bk. 4: 6-10 (6st. nos. 5, 4, 9, 6, 7, 8; st. 9 translated), Bk. 5: 102-104, frag. (first three st.), Bk. 10: 127v-128r (9st. plus part of 10th), Bk.

19 The Manx carval (cf. G carbhall) is a religious folksong or carol seemingly of Reformation provenance, though possibly descended from an older ballad/bardic tradition (cf. Quiggin 1913). A full catalogue of all extant carval mss. (dating from the eighteenth and nineteenth centuries), is available in the Library of Manx National Heritage, Douglas. 
12: 1-5 (8st.), Bk. 16: 35-37 (9st. plus pa of 10th) MNHL MS H140 6594 (Bk. 12; 8st.), MTSSF/II: 8-11 (Bk. 16).

Typescript: by Thomas Moore (1836-1923), Brookfield, Port Erin RU, 91/2 st. no title MNHL MS 5298/2C (Paton 1944: 131-132, ent. 'Loss of the Fishing-boats at Port St. Mary in 1846' from an untitled ms. by Thomas Moore, Brookfield, Port Erin. Author of text unknown). Paton (1944: 131) adds:

[...] but in spite of the title of the ballad, I am not sure that any were actually destroyed. Mr. John Gawne [1881-1977] of Fistard tells me that no lives were lost (Paton 1944: 131).

Printed versions: Under the title Yn Sterrym ec Port le Moirrey (the storm at Port St. Mary) (1st. 3 stanzas with Eng. trans.) in Moore (1896: 184 from William Cashen, Peel); also in Cashen (1912: 68-69); 1st 3 stanzas. with above title \& Eng. trans. Tune: No tune known. But as this song is in the same metre as Arrane mysh Coayl ny Baatyn-skaddan (\$2.4), Gilchrist (1924-1926: 120-121) notes that the tune is often used for songs about shipwreck.

Tells of the wreck of the herring fleet at Port St. Mary in 1846.

ARRANE MYSH COAYL NY BAATYN-EEASTEE (song frag.). Joseph Woodworth (1853-1931), Smelt, Port St. Mary, Rushen, 27 August 1930 (M/III: 1692; HLSM/I: 392-393).

\author{
du:'t 'nedi hom 'rei \\ də røu a 'fe:dzə 'fi: xrei \\ də røu a nə 'bö:r ən 'ke:ßəl də 'ga:rə \\ a'ne: du:rt dzo:s 'beg \\ bi:mad 'sta:i عrə 'xreg \\ as ol'u 'bcit' ũns [tonən] nə 'ma:rə
}

\author{
Dooyrt Neddy Hom Ruy ${ }^{20}$ \\ dy row eh sheidey feer chreoi \\ dy row eh ny bare (sic) yn caabyl y giarrey \\ Cha neh, dooyrt Jose Beg \\ beemayd sthie er y chreg \\ as ooilley baiht ayns (tonnyn) ny marrey.
}

[Said Neddy Hom Ruy / it was blowing very hard / that it would be better to cut the cable / Not at all, said Jose Beg / we'll be in on the rock / and all (of us) drowned in the waves of the sea].

ARRANE MYSH COAYL NY BAATYN-EEASTEE (song frag.)

Ned Maddrell (1877-1974), Glenchass, Rushen, 18 February 1953 (YCG/12; IFC/40 (April/May 1948), LSS/902 24 August 1972; HLSM/I: 354-355).

The following three stanzas are also to be found in Moore (1896: 184).

20 i.e. Edward Faragher, Sr. (1803-1890), farmer-fisherman, Cregneash, Rushen. Ned Maddrell knew him personally, cf. HLSM/I: 348-349. 
I

o: mə g'il'ə[n] va:i

to $\int \mathrm{m}$ nI $\int$ egə ta:i

ha 'dzigmæd gəsı nö:tkə nə 's ${ }^{\mathrm{d}} 3 \varepsilon$

ha dzInmad dza'ru:d

In 'stïrəm heyk $\int$ in tru:d'

ag 'ankp a: bai pü̈t lo 'morə

II

dut 'nedi həm 'ræ-i:

də rau o 'fe:3ə fi:ə 'kræ-i:

as ha 'bö:r l'In In 'kö:bəl a 'g'a:rə

ha dzIdn dut dzo:ds 'bed [beg]

biməd's ft'a:x ərə kreg

as ซl'u 'k'ál't' ซns nə 'tønən nə 'ma:ră

III

van 'gud ən'tent

væi 'be:ðə mai 'ḑint

vai 'playkit wu ta $\mathrm{ta}^{1} \mathrm{ax}$ gəs dzere

fe: ' ' ${ }^{1}{ }^{1}$ ax fi: ə vo:1

ve: rən 'midsømə go:1

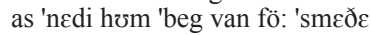

O my guilley[n] vie

ta shin nish ec $y$ thie

Cha jigmayd gys yn aarkey ny sodjey

Cha jeanmayd jarrood

yn sterrym haink shin trooid

ec anker er Baie Purt le Moirrey

Dooyrt Neddy Hom Ruy

dy row eh sheidey feer creoi

as cha bare Ihien yn caabyl y giarrey

Cha jean, dooyrt George Beg

beemayd stiagh er $y$ creg

as ooilley caillt ayns ny tonnyn-ny-marrey

\author{
Va'n 'Good Intent' \\ v'ee baatey mie jeant \\ v'ee plankit woish toshiaght gys jerrey \\ She sheshaght feer voal \\ v'er yn 'Midsummer' goll \\ as Neddy Hom Beg' ${ }^{21}$ yn fer smessey.
}

[1. O my good lads / we are now at home / we shall go to sea no more / we shall not forget / the storm we came through / at anchor in Port St. Mary bay.

2. Neddy Hom Ruy said / that it was blowing very hard / and we had better not cut the cable / No, said George Beg / we shall be in on the rock / and all drowned in the waves of the sea.

3. The 'Good Intent' / she was a boat well built / she was planked from stem to stern / it was a very sluggish crew / that was aboard the 'Midsummer' / and Neddy Hom Beg was the worst of them].

\subsection{ARRANE MYSH COAYL NY BAATYN-SKADDAN (a song about the loss of the herring} boats) (song frag.)

Text: Manuscript versions: Thomas Cowin, Ballabeg LO, 23st. ent. Arrane son Coonaghtyn Jeh ny badyn va Callyt (a song for remembering the boats that were lost), dated 17 December 1820, MNHL MS 5078A; Thomas Cowin 1855 ('went to America') 23st. ent. Arrane Son Cooinaghtyn jeh ny baadyn va Caillit MNHL MS 272. In Carval Book of Wm. Collister 1838-1842, 18st. no title, MNHL MS 1402A (G. W. Wood Coll.), Clucas Coll. ent. [Arrane mysh] ny Baatyn va kallit (a song about the boats that were lost) (19st.) (MTSSF/I: 11).

Printed versions: Harrison (1869: 80-89; 18st.) with Intro.; text ent. Arrane mysh ny Baatyn-skeddan va caillit ec Doolish 'sy vlein 1787, Sep. 21st. Note: 'The author of this is Quayle Vessee'. Broadside printed by Juan Christeen Faragher, Mona's Herald, Douglas, 18st. ent. Arrane mysh ny Baatyn-Skeddan Va Caillit ec Doolish

21 Alternative form: Neddy Tom Peg (Neddy son of Tom, son of Peg) in Moore (1896: 184). 
'sy vlein 1787, Sep. 21st, with Eng. trans. n.d. [c. 1870]. Broadside 'Destruction of the Manx Herring Fleet in Douglas Bay, on St. Matthias' Night, [21] Sept. 1787'. In pencil is marked 'edited by John Cottier'. Douglas: J. C. Faragher n.d. [c. 1872]. Broadside 'An Account of the Loss of the Manx Herring Fleet on the 21st September 1787, with the Ballads in Manx and English,' ed. William Harrison. Douglas: Matthew Glover, 1872, 37pp (MNHL MS J8 2X F1\&2). Moore (1896: 150-153; 18st. ent. Coayl jeh ny Baatyn-Skeddan with Eng. trans., from Harrison 1869).

Tune: Clague: Version 1 C3/43: 3 John Cain, ent. 'Herring fleet', Douglas, Version 2 C3/36: 2 Mary Gawne, Peel, ent. 'Herring fleet', Version 3 (C1/14: 4) John Ratcliffe, The Howe RU, ent. Trooid shiu ooilley gethan vie (come ye all to the good) (carval) (Gilchrist 1924-1926: 120-121, 121-122). As Gilchrist (19241926: 121-122) notes:

Dr. Clague seems to have noted six versions, three of which, including a Dorian form, are printed in Manx National Music $(32,44,48)$. The variant obtained from John Ratcliffe, The Howe, was used as a carval-tune [...]. The tune seems to have been one used for ballads of shipwreck [...] (Gilchrist 1924-1926: 121122).

But two other tunes also noted: C4/22: 6 ent. 'Loss of [the] herring fleet' $\mathrm{E}$. Corteen [Maughold], C4/26: 5 'Loss of [the] herring fleet' P. Caine [Baldwin]. Moore (1896: 240, 241) gives two versions of the tune from John Cain, Douglas, and Mary Ann Gawne, Peel, respectively, but, as noticed by Gilchrist (1924-1926: 121), noted rather differently.

This song relates to the loss of a portion of the Manx herring fleet which happened off Douglas Harbour on 21 September 1787 when some fifty vessels were either totally wrecked or very badly damaged and twenty-one ${ }^{22}$ lives lost in a severe storm. The song was apparently written by a certain Quayle Vessie (Quayle son of Bessie) of Castletown (Moore 1896: xxxvi). For details of the loss, see Harrison (1872: 5-12).

ARRANE MYSH COAYL NY BAATYN-SKADDAN (song frag.) Edward Kennah (1860-1938), Ronague, Arbory, 27 August 1930 (M/IV: 2499; HLSM/I: 396-397).

22 In a footnote to an English poem on the tragedy (Harrison 1872: 25 note), it would appear from stanzas IV and V '...that the crews of three boats [editor's italics] and one old man only, were lost. Assuming that each boat had five men, this would only account for sixteen, whereas the other ballad [in Manx] makes the number amount to twentyone.' 
kuni fu fedn as ' $\varepsilon: \mathrm{g}$ erə 'vli:dn $\int \varepsilon: x$ x'id 'dyeg ke:r 'fid'as ' $\{\varepsilon: \mathrm{x} \varepsilon r$ kidn 'yuli tre: hink a mə'k' ə:n [sic] ve 'ji:stax va:i o:n

l'e $\int^{\prime}$ 'irif fi: ' $\varepsilon: l i n '$ as 'mïlif

\author{
Cooinee shiu shenn as aeg \\ er y vlein shiaght cheead jeig \\ kiare feed as shiaght er keayn Ghoolish \\ tra haink eh mychione $[\mathrm{sic}]^{23}$ \\ va eeastagh vie ayn \\ lesh earish feer aalin as millish.
}

[Remember ye old and young / the year seventeen hundred / eighty-seven on the sea at Douglas / when it came about / there was good fish to be had / and the weather was very fine and pleasant].

\subsection{ARRANE OIE VIE (Good night song) (song frag.)}

Text: Clague Bk. 5: 50, Bk. 10: 130v. Printed texts: Moore (1896: 58; 2st. from various sources, not specified), Mona Douglas (1928: 32-33: Tom Taggart, Malew, 2st.), MTSSF/II: 5 (Bk. 5).

Tune: C1/3: 1 E. Corteen, Surveyor of Roads (ent. Te traa gholl thie dy gholl dy lhie (it is time to go home to go to bed); Thie Quiggin (Quiggin's (ale-)house), and C4/23: 1 E. Corteen; in Gilchrist (1924-1926: 186-187). The Manx tune, according to Gilchrist (1924-1926: 188), seems to belong to an early type of folktune. She adds:

The rhythm of these short detached phrases has a foundation in nature in the regular rise and fall of the breath - the cæsura corresponding with its expiration. It might be called 'breathing measure.' In the Manx song, the rhymes come upon these natural resting-notes (Gilchrist 1924-1926: 188).

A Manx 'Good Night' song traditionally of two stanzas. This would seem to belong to a genre of convivial parting or goodnight songs found in Scotland, Ireland and Man, but not in England, which even today has to borrow Auld Lang Syne for the ending of festive gatherings. The Manx version recollects the older Irish parting song Níl sé 'na lá (Gilchrist 1924-1926: 185). The Manx Te traa goll thie (it is time to go home) is reminiscent of similar Scottish songs having short melodic phrases, the tune attached to it a variant of 'Geordie'. See JFSS V (1923): 110-114 for eight versions of the Manx tune.

The Manx Arrane Oie Vie was the last song sung at the end of an Oie'll Voirrey, ${ }^{24}$ a protracted session of carval singing on St. Mary's Eve (Christmas Eve), after which most of the company adjourned to a local hostelry for hot-spiced ale after which the revellers sang Arrane Oie Vie then went to bed (Gilchrist 1924-1926: 187).

23 gy kione '[came] to pass/about', as in Moore (1896: 150) and Gilchrist (1924-1926: 120).

24 Pron. /i:1 'veri/ (G *oidhche fhéil' bheiridh). 
ARRANE OIE VIE (song frag.)

James Cannell (1816-1903), Kirk Michael (of Peel) with wife (of Michael), 26 July 1890 (Rhŷs 6/69-70).

$\mathrm{t}^{\mathrm{h}} \mathcal{E} \mathrm{t}^{\mathrm{h}} \mathrm{r} \varepsilon$ : $\partial ə$ gol 'thai as gol ðə lai tha sməl ðəu ţət $\varepsilon \mathrm{r}$ ən ãil ${ }^{25}$
T'eh traa goll thie as goll dy lhie

ta smayl dhoo çheet er yn aile.

[It is time to go home and go to bed / a blackness is coming on the fire].

ARRANE OIE VIE (song frag.)

Thomas Christian (1851-1930), Ramsey, June-July 1929 (M/II: 737; HLSM/I: 228-229).
ti tre: gol 'ta:i
də gol də teï
T'eh traa goll thie
t $\varepsilon$ 'fo:d døu ərə 'tfalax
dy goll dy lhie
ten 'sto:l't $\varepsilon$ fo:n'
Ta foaid dhoo er $y$ çhiollagh
gre: dən'gol ro:n'
ti ta:n gös tre: ən laßax
Ta'n stoyll ta foin
gra dooin goll roin
T'eh tayrn gys traa yn lhiabbagh.

[It is time to go home / to go to bed / the turf-sod is black on the hearth / The stool that is under us / says to us to go our way / It is getting near to bedtime].

\section{ARRANE OIE VIE (song frag.)}

Thomas Taggart (1846-1933), Grenaby, Malew, 27 August 1930 (M/IV: 2479; HLSM/I: 390-391).

\author{
ti tre: gol ta:i \\ as gol ðə la:i \\ t $\varepsilon$ fo:d döu erə talax \\ t $\varepsilon: n$ sto: $1^{\prime}$ t $\varepsilon$ fo:n' \\ gre: hə:n' go:l ro:n' \\ ti ta:'rn gəs tre: ən l'abəx
}

\author{
T'eh traa goll thie \\ as goll dy lhie \\ Ta foaid dhoo er $y$ çhiollagh \\ Ta'n stoyll ta foin \\ gra hooin goll roin \\ t'eh tayrn gys traa yn lhiabbagh.
}

[It is time to go home / and go to bed / the turf-sod is black on the hearth / The stool that is under us / says to us to be on our way / It is getting near to bedtime].

ARRANE OIE VIE (song frag.)

Joseph Woodworth (1853-1931), Smelt, Port St. Mary RU, 27 August 1930 (M/III: 1658; HLSM/I: 392-393).

25 Known in Manx as Arrane Oie Vie ('The Good Night Song'). For the full text of two stanzas, see Moore 1896: 58. 
t $\varepsilon: n$ 'sto:l t $\varepsilon$ fo:bm

tre:1'gre: 'ro:bm

ti: 'ta:'n hrk 'tre: ən 'l'aßax
Ta'n stoyll ta foym

tryal gra roym

t'eh tayrn hug traa yn Ihiabbagh.

[The stool which is under me / is trying to say to me / it is getting near to bedtime].

\subsection{BRIG LILY (song frag.)}

Text: Manuscript: (Manx) John Nelson, Fistard, Port St. Mary, Rushen 1853, ent. 'Lines on the Awful Catastophe of the Lily', 26st. MNHL 428A.

Printed text: Broadside ent. "Lines on the late Awful Catastrophe of the "Lily" by John Nelson', 26st. M. A. Quiggin, Printers, 52, North Quay, Douglas (before 1862). In Isle of Man Examiner 29 January 1926 ent. Moorchooir y Vrig Lily (Wreck of the Brig Lily) 26st.

English text by Thomas Shimmin (nicknamed 'Tom the Dipper')(1899-1876/1879), 11st. ent. Yn Coayl jeh 'n Lillee (the loss of the Lillee), c. 1860. Broadside. No place or printer. 'The Wreck of the Brig Lily. A ballad by John Nelson of Kirk Christ Rushen, trans. into English by P. W. Caine', printed in the Isle of Man Examiner 22 January 1926 (Cubbon Bib. II: 803).

Tune: Clague C1/4: 2 ent. Brig Lily; tune widely known, e.g. in Ireland as 'The Croppy Boy'. cf. also Gilchrist (1924-1926: 317, 323). The title is given in English by Clague but belongs to the Manx-Gaelic song repertoire.

Sailing from Liverpool and bound for Africa the brig Lily was shipwrecked on the rocks off the small island of Kitterland in the Calf Sound (between Man and the Calf of Man) on 28 December 1852. A sudden explosion of thirty tons of gunpowder, apparently caused by a forgotten candle stub left by a number of men seeking to salvage the cargo, instantly killed five crew and twenty-nine salvagers, mostly from Port St. Mary. A memorial stone to those who lost their lives stands in the churchyard of Kirk Christ Rushen (Illustrated London News, 8 January 1853), as does one erected during the 1990s at the Sound.

BRIG LILY (song frag.).

Ned Maddrell (1877-1974), Glenchass RU, 18 February 1953 (YCG/12; also PR1 (1947), IFC/40 (April/May 1948); HLSM/I: 352-353). 
I

b'1'i:n'ha:x kid 'dzeg gai 'jeg as $\mathrm{da}^{1} \mathrm{~d}^{\prime} 3$ In 'atfi ' 'ऽ: nax 'bon dən' 'l'ed's dzai 'de:n'o as 'fid do dzidn va 'streit's l'e $\int$ 'aĩl' as 'pu:ðə fi:ə döl'tat's

\section{II}

brig lili va-i: wu1 $\int^{\prime}$ 'lı $\tilde{\varepsilon}$ 'pu:1 gəs 'afrr'ke: va-i 'k' $\varepsilon$ :rit 'gøl ax' 'stırəm 'mu:r rain' 'gait i 'tfodn 'ft'a:x ərən 'al'an 'kïtəlan ${ }^{\text {d }}$

\section{III}

nə 'de:n'ə 'J̃̃ va 'lo:rət ru:

'sõn də sa:'ue:1'ən 'brig as 'stu: az 'ro' ${ }^{1}$ va 'tre: pk 'saue:1'veg hai 'brig as 'dön'ə sëis dzen kreg

Sen 'rl'u ta 'ku:n'axtən em $\varepsilon:{ }^{r}$, ax ta 'ronə il' $\varepsilon$

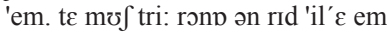

\begin{abstract}
Blein hoght keead jeig gaa yeig as daeed yn atçhim shoh nagh bione dooin 'lheid Jeih deiney as feed dy jeean va stroit lesh aile as poodyr feer doaltatt
\end{abstract}

\begin{abstract}
Brig Lily v'ee woish Liverpool gys Africaa v'ee kiarit goll Agh sterrym mooar ren geiyrt ee çhionn stiagh er yn ellan Kitterland
\end{abstract}
Ny deiney shoh va loayrit roo son dy sauail yn brig as stoo
Agh roish va traa oc sauail veg hie brig as deiney seose jeh'n creg.
Shen ooilley ta cooinaghtyn aym er, agh ta ronney elley aym, t'eh mysh tree ronney yn red elley aym.

[1. The year eighteen hundred and fifty-two / this horror we have not known the like / thirty men were exterminated / very suddenly by fire and powder.

2. The Brig 'Lily', she was from Liverpool / to Africa she was bound / But a great storm drove her fast / in on to Kitterland island.

3. These men had been told / to save the brig and its cargo / But before they had time to save anything / the brig and men went up (exploded) off the rock.

That is all I remember of it, but I have another verse, it is about three verses, the other one I have].

\subsection{COLBAGH BRECK ER STHRAP (speckled heifer on a tether) (song frag.)}

Text: Clague Bk. 5: 98-102; 12st. \& refr. as in MNHL MS unacc. (Clarke) for Harrison (1873: 108-119) and Moore (1896: 83 ent. Car-y-Phoosee (wedding reel), MTSSF/II: 2. Moore (1896: xxii) believes that the song was written by Rev. Philip Moore (1705-1783), part-translator and editor of the Manx Bible, c. 1750. ${ }^{26}$ (Moore 1896: xxii-xxiii), but takes the view that the refrain is of much older date. Tune A: Clague C1/19: 2 Mrs. Lawson, Jurby East; C3/37: 3 Thomas Kinraid, Ramsey ('played on fiddle') (Gilchrist (1924-1926: 173); C3/44 note: [John Cain, Douglas] 'sang "Colbagh Breac" as played by Kinraid', C4/26: 4 ent. Yn Colbagh Breck er strap, also Eng. 'The speckled heifer tethered', also Car y phoosee P[hilip] Caine, Baldwin, Moore (1896: 237 Philip Caine ('Phillie the Desert'), Baldwin) ent. Car y Phoosee (Wedding Song). Another tune collected by Mona Douglas from Robert Kerruish, Ballavelt, Maughold, with English words (Mona Douglas Coll.: 13). Gilchrist (1924-1926: 173) notes:

26 For details of Rev. Philip Moore and the Manx Bible translation, see Thomson 1979: Introduction. 
There are two other tunes of this name from the Clague Collection in W. H. Gill's Manx National Music [1898: 42, Manx National Songs 1896: 47, 98]. Both appear to belong to a song or dance-song with a chorus ('Chorus' being marked in one case [1896: 98]). But the one printed here [i.e. from Thomas Kinrade, Ramsey, and John Cain, Douglas], and the melody is in 3-bar phrases instead of the usual 4-bar, as in the case of the two others. All are of lively character and in 3/4-time, and appear to me to be dance tunes, under which heading I have therefore placed the above [Kinrade \& Cain] version (Gilchrist 1924-1926: 173).

Tune B: Moore (1896: 238 Mary Ann Gawne, Peel).

The song discusses the vagaries of married life, but reveals the benefits. Moore (1896: xxii-xxiii).

COLBAGH BRECK ER STHRAP (song frag.).

John Cain (1850-1939), Ballamoar, Jurby, 2 February 1933 (M/IV: 2635; HLSM/I: 314-315).

I sõn va:n 'kolbax 'brek er 'strap ne hĩ:n' vع 'sauər

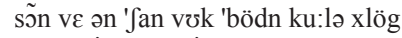
t $\varepsilon$ : nən 'a:ru üsə 'nauər

\section{[Refrain]}

pu:s o 'pu:s o 'pu:s

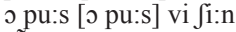

son vi 'fa:ðə ' ' $\varepsilon^{\mathrm{r}}$ vi 'pu:s

an i ad vi 'ta:lu dzi:n'

\section{II}

hïjk 'ben a fu:ði $\int t^{\prime} a: x$

$\int e e^{r}$ a frïngbag bei

də røu Jin'a fu:ðə us trei

ha røu fin'üs sted'a trei
Son va'n colbagh breck er sthrap nee hene vees souyr son va yn shenn vock bane cooyl y chleigh tayrn yn arroo ayns yn ouyr

Poost oh poost oh poost oh poost [oh poost] va shin Son v'eh foddey share ve poost cha nee ad ve taggloo jin

Haink ben y phoosee stiagh share y ?springbok beiy (sic) dy row shin er phoosey ayns traa cha row shin ayns stayd cha treih.

[1. For the speckled heifer was on a tether / is it not it which will be snug / For the old white bock behind the hedge / was drawing the corn in the harvest. [Refrain]: Married, oh married / oh married, oh married were we / For it was better to be married / (than) that they talk about us.

2 . The bride came in / better the springbok ${ }^{27}$ beast / had we married in time / we would not be in such a sad state].

27 The reference here to the South African antelope, the 'Springbok' (if that is what is meant; the spoken version is not all that clear) might at first seem surprising. But South Africa was no strange place to many a Manxman who went out there to work in the mines during the late nineteenth and early twentieth centuries (NHIM/V: 235). 
COLBAGH BRECK ER STHRAP (song frag.)

Mrs. Annie Kneale (1864-1949), Ballagarrett BR, April/May 1948 (IFC/39, also IFC/36; HLSM/I: 308-309).

I

an 'kp:lbax 'brek $\varepsilon$ : 'strap

no 're: hi:dn vis 'sauər

In Jan bok 'bedn go'le:ig'

t $\varepsilon:$ 'n $ә$ ' 'a:ru sən 'auər

\section{[Refrain]}

he pu:s [as 'pu:s as 'pu:s]

as pu:s ठə 'l'u:ə va fi:n

te 'fэ:ðə ' $\varepsilon \varepsilon$ : ve 'pu:s

na nع (sic) 'ta:"lə (sic) 'smeðə ve 'dzi:n

II

a[s] 'gaun ðə 'linzi 'wrnzi

as 'bonad 'bedn sa'lu:n

as 'kwaif ðə 'fa:n l'i:n skaðan

as 'rrbanən spi'n'e:g'ín 'x'u:n
Yn colbagh breck er sthrap nagh re ee hene vees souyr yn shenn bock bane goll eig tayrn yn arroo syn ouyr

Hey, poost [as poost as poost] as poost dy liooar va shin T'eh foddey share ve poost na'n taggloo smessey ve jin
As gown dy linsee-wunsee ${ }^{28}$ as bonnad bane shalloon ${ }^{29}$ as quoif dy shenn lieen skaddan as rybbanyn spinneigyn huin

[1. The speckled heifer on a tether / is it not itself that will be snug / The old white bok is failing / drawing the corn at the harvest.

[refrain]: Hey, married (and married and married) / and married enough were we / It is far better to be married / than to have the worst said of us.

2. And a gown of linsee woolsee / and a white bonnet of shalloon / and a quoif of old herring net / and ribbons of peeled rushes].

\subsection{CRE'N SORÇH DY 'WRECK' (what sort of wreck) (song frag.)}

Text: Clague Bk. 12: 15 (4 st.), MTSSF/II: 11-12 (Bk. 12).

Tune: No tune known.

CRE'N SORÇH DY 'WRECK' (song frag.)

James Kewley (1849-1939), Maughold, 21 August 1929 (M/Diary 52; HLSM/I: 318-319).

ken sörty də rek də hai krog ḑek ə nörəxə męx on g' ourə vi dзent mə ge:i วs'k'u:n ə ve:i son fo:si ənsə tourə
Cre'n sorçh dy wreck dy hie chrog Jack cha nuirragh eh magh un geurey V'eh jeant myr gaih erskyn y Vaie son $\mathrm{p}(\mathrm{h})$ osey ayns $\mathrm{y}$ tourey.

28 linsee woolsee or linssy-wulssy: 'cloth made of linen and wool' (MMG/110).

29 Re: shalloon, cf. Gilchrist 1924-1926: 170 note: 'A light kind of woollen stuff, used for coat-linings, said to have derived its name from having been manufactured at Châlonssur-Marne.' 
[What sort of a 'wreck' of a house did Jack build / It will not last one winter / It was built like a toy above the bay / for a posey in the summer].

Seemingly a sarcastic reference to the Castle Mona, built in opulent style in 1804 for John Murray, Fourth Duke of Atholl and Governor of Man (1793-1830), as a place of residence. It is now a hotel. For a fuller text see MTSSF/II: 11-12.

\subsection{EC NY FIDDLERYN (at the fiddlers) (song)}

Text: Oral version (521i./13st.) in phonetic script with English translation collected by John Strachan and Richard Henebry from Tom Kermode, Bradda RU, summer 1883 ent. 'A Manx folksong' and published in ZCP I (1897): 54-58. ${ }^{30}$

Manuscript versions: MNHL MD 900 MS 08307: 20-22 n.d. [c. 1830-1840] 15st. ent. Eg ny fidleryn ayns yn Ullic (at the fiddlers at Christmas time), Clague Bk. 5: 50, 10: 130r, 16: 154 (all contain 1st quatrain) (c. 1896) MNHL MS 450A (Archdeacon John Kewley Coll.) MTSSF/II: 13 (Bk. 5); Clucas Coll. 6st. in hand of George Frederick Clucas (1870-1937) MNHL MS 263A, possibly copied c. 1900 from an ms. in the hand of Rev. John Thomas Clarke (1798-1888), a collector of Manx traditional songs c. 1860s (MTSSF/I: 18-19, 6st.); MK/M19 (1905) MNHL MS 09495 (Box 4) $)^{31}$ (5st. or part quatrain).

Printed versions: Moore (1896: 218-221; 13st. from Strachan \& Henebry with Eng. trans.); Roeder (1896: 179; frag. of 8 lines beginning Dy row my milley er my doosey (may my curse be on my girl), Moore (1896: 108; 4qq from Robert Gawne mss.) ent. Mârish ny Fiddleryn (with the fiddlers).

Tune: Clague C1/28:1 Tom Kermode, Bradda RU ent. She ec ny Fiddlern ayns yn Ollic (it was at the fiddlers' at Christmas time); C1/13: 2 John Ratcliffe, The Howe RU ent. Ec Norree yn Fiddler (at Norree the fiddler); C4/27: 6 W. Corlett [Minorca] ent. Ec Ollick Ball ny Fiddleryn (at the fiddlers' Christmas ball); Manx version a direct trans. from the English). Other variants: C3/35: 2 Thomas Crellin, Peel, ent. Yn Shenn Dolphin (the old Dolphin [name of boat]), C3/35: 3 Mary Ann Gawne, Peel (with same title). ${ }^{32}$

Anne Gilchrist (1924-1926: 132-134) prints four versions of the tune: 1) Ayns yn Ollick ec Ball ny Fiddleryn (at Christmas at the fiddlers' ball) without accreditation [but W. Corlett above] with 1st verse taken from Moore (1896:

30 For a detailed discussion of the manuscripts and contents of this song with linguistic notes, see Broderick: 1984b.

31 For a detailed analysis and discussion of the Morrison-Kermode song collection, see Broderick: forthcoming I.

32 According to the minutes of the 1905 meeting of the Manx Language Society, the song Ec ny Fiddleryn was recorded on wax cylinder (apparently in 1904) from Edward Cubbon and John Cregeen, Peel, around that time. Also recorded at that time were: Hop-tu-naa, Ny Kirree fo Niaghtey, and Mylecharaine, cf. Miller 2014: 1-9. 
108), 2) John Ratcliffe's version, 3) Tom Kermode's version, 4) Thomas Crellin's version. With regard to these versions Gilchrist (1924-1926: 133-134) remarks:

[..]. Three versions of the tune are found in Moore $(1896: 245,250,238)$ - the last sung to "Yn Çhenn Dolphin". The version on p. 245, under the title "Graih My Chree" ('love of my heart') has a single verse probably belonging to another song, though it might have formed a refrain to the "Ec ny Fiddleryn" verses. This variant was obtained from the singer of Version 4 above [...]. Miss [Lucy] Broadwood has noticed the likeness in Versions 1, 2 and 4 to the Gaelic air "Mo rùn geal dileas, dileas, dileas" ('my loyal brave love'). This is also evident in Moore's version p. 238 of "Yn Çhenn ${ }^{33}$ Dolphin" - yet another variant, though disguised by wrong barring, of Versions 1,2 and 4 above (Version 3 appears to me to be a different tune) [...] (Gilchrist 1924-1926: 133-134).

With regard to the content of the song Gilchrist (1924-1926: 133) notes:

The story is of a false love; after a long courtship the girl, renewing her vows to her betrothed on the Sunday before Ash Wednesday, marries another on Ash Wednesday morning. The only witness of their troth-plight was a dumb walnut tree; but [in] spite of her falseness, Greenland's snow will grow red as roses before he forgets her (Gilchrist 1924-1926: 133).

John Strachan (1862-1907), Hulme Professor of Ancient Greek and Professor of Sanskrit and Comparative Religion, as well as of the Celtic languages, at Owens College, later the Victoria University of Manchester, visited Man in 1883 along with Father Richard Henebry (i.e. Risteart de Hindeberg 1863-1916 of Co. Waterford), an Irish priest, Irish language activist and musician, who worked in Salford, Manchester. ${ }^{34}$ They interviewed Tom Kermode (1825-1901) of Bradda, Rushen, when Strachan took down from him in his own phonetic script (here in IPA script) Kermode's version of the Manx traditional song Ec ny Fiddleryn. Strachan visited Kermode alone in September 1895 and took it down from him again. ${ }^{35}$ As noted above, Strachan printed the song under the title 'A Manx Folksong' in ZCP I (1897): 54-58. In supplying details of the background to collecting this song Strachan writes:

33 Shenn in Moore (1896: 238).

34 I am advised by Ciarán Ó Gealbháin, University College Cork, that Strachan and Henebry knew each other, as they apparently had a mutual arrangement whereby Strachan would teach Henebry Old Irish and Henebry Strachan Modern Irish (p.c. 25 August 2017).

35 Father Henebry, too, returned to Man on his own 'six years later' (i.e. in 1889), but to visit Edward Faragher (Ned Beg Hom Ruy) (1831-1908), according to a letter from Faragher to Karl Roeder dated 25/12/[1889] (MNHL MS 2146/6A). Henebry evidently told Faragher that he had obtained some Manx songs from Tom Kermode [in 1883], which Faragher had apparently not come across ('but I never come across any of them') (Miller 2019 (Manx Notes 20 (2004)): 2). 
In the summer of 1883 I spent a few days at Port Erin in the Isle of Man along with Father [Richard] Henebry, from County Waterford, Ireland, who speaks Irish as his native tongue. During that time we went about among the surrounding villages to see if we could discover any of the old folksongs or folktales of Man. For the most part our search was unsuccessful. The people have ceased to care for these things, and so they have fallen into oblivion. ${ }^{36}$ But as a compensation for many disappointments we were lucky enough to obtain the following sweet little song from a genuine Manxman, Thomas Kermode of Bradda, near Port Erin, who, though he lost his eyesight in his boyhood, pursued till about three years ago [c. 1892] the calling of fisherman. He recited the song to us, and explained it, and we took it down as well as we could. In September of the present year [1895] I again visited Man, and I had the song recited to me again. Unfortunately Mr. Kermode was ill during part of my visit, and I was unable to see as much of him as I could have wished. Above anyone whom I met he is interested in and acquainted with the old lore of Man, though he told me that he had not heard a Manx song sung for the last forty years [i.e. since c. 1840s] (Strachan: 1897: 54). ${ }^{37}$

With regard to this song, Moore (1896: xxi, footnote) adds:

This was first obtained from Thomas Kermode, Bradda in 1883 by Professor J. Strachan and Father Henebry, and was published in phonetic Manx with a good translation in the Zeitschrift für Celtische Philologie, in March last. ${ }^{38}$ Mr. W. J. Cain ${ }^{39}$ has since then seen Kermode and has satisfied himself of the general accuracy of this version which he and I have translated (Moore: 1896: xxi, footnote).

Strachan then proceeds to detail his phonetic rendering of the song-text with reference to Rhŷs (1895). He then prints the text in his phonetic script and supplies an English translation.

36 This is not quite the case, as both Rhŷs (1886-1893) and Roeder (1890s/1900s) were able to collect quite a fair bit of folklore material during their visits to Man, cf. Rhŷs: 1891, 1892; Roeder: 1904.

37 Strachan's September [1895] visit to Man is perhaps to be seen in his wish to have a contribution from Man for the first issue of the Celtic academic journal Zeitschrift für celtische Philologie in 1897. As already noted, the song-text appeared under the title 'A Manx Folksong' (Strachan: 1897: 54-58). Tom Kermode was the principal singer for Dr. John Clague whom Clague met for the first time in late December 1895 (Letter Dr. Clague - Deemster J. F. Gill 25/12/1895 MNHL MS 09702 Deemster J. F. Gill Papers, Box 2) and obtained much song material from him during 1896.

38 As Miller (Manx Notes 20 (2004): 2) points out, Moore's Manx Ballads and Music appeared during the year 1896, which would indicate that Moore's "March last" would refer to that year. This, if correct, would imply that ZCP I came out in March 1896, and not in 1897 as listed.

39 William Joseph Cain (1826-1911), Douglas, one of Moore's editorial assistants for his Manx Ballads and Music (Miller: 2017, Part. 8). He was also one of Rhŷs's main informants (see Broderick 2018b: 37ff.). 


\section{EC NY FIDDLERYN (song).}

Tom Kermode (1825-1901), Bradda, Rushen, summer 1883 (Strachan \& Henebry. Zeitschrift für celtische Philologie I (1897): 54-58). The text in Strachan is set out in a block of 52 lines, implying thirteen four-line stanzas as indicated by the tunes cited above. For ease of reference the text and translation are provided here in thirteen stanzas.

I

عk nə fidl'arən əðən ulik ven x'əd vo:1 vi:t mi rï grai mə xri: də graiax graiax həi fin $\int 1$ :s kudzax as hug Jin təijax ðən tu:r'i:

II

wi: ən u:r ${ }^{\mathrm{j}}$ in dəs k'odn $\int^{\prime} \mathrm{ax}$ bl'i:ənə ve: mə yrai ps mif menik me'de: $1^{\prime}$ ps jal i: dü:s l'ežə t'finə folsa na: d'zinax i: mi də brax xr'e'ge:1'

III

fastər d'zə'dü:ni ro $\int 1 \varepsilon$ : inid hai mi də ji:yən grai mə xri: hog i nə d $\varepsilon$ : leu os mə ye: leu na bu:ðax i: fer erax ax mi:

IV

heyk mi rom tai as mə xri: də gen'al n'ji: erbi: ha rau d'zinu sə:yən dü:s ən $x^{\prime}$ əd ski:əl xy:1 mi ma:ri le: inid də rau mə yrai rij fer el'ə pu:s

V

drau mə vi:1'ə erə du:ði ps mi su:ri ซri rï xwel'on $l \varepsilon$ : tra hanik i: na rau grai $\varepsilon \mathrm{k}$ orəm ๖ðax i: ve ən obal tre:

VI

ha d'zinəm d'zi: $\int$ draxlu nə gweən ha wiðəm draxfart' $\int ə n$ də hit nə re:d ax də d'zin i bo:ə de ə kar'd'zən ge ठə vel i ə jinu d'zi:ms ax krع:'d'

VII

ən bil' ə walnut na redn r'ju ta:lu finif erax ha rau $\mathrm{cm}$ nif t $\varepsilon$ : mə yrai ə fraual də folsa as tə mi fe:yit mə lumarkən
Ec ny fiddleryn ayns yn Ollick

v'eh chied voayl veeit mee rish graih my chree.

Dy graihagh, graihagh hie shin sheese cooidjagh as hug shin toshiaght da'n tooree.

$5 \quad$ Veih yn oor shen dys kione shiaght bleeaney va my ghraih as mish mennick meeiteil as yiall ee dooys lesh e chengey foalsey nagh jinnagh ee mee dy braagh hreigeil.

Fastyr Jedoonee roish Laa Innyd

I0 hie mee dy yeeaghyn graih my chree. Hug ee ny daa laue ayns my ghaa lau nagh boosagh ee fer arragh agh mee.

Haink mee roym thie as my chree dy gennal nhee erbee cha row jannoo seaghyn dooys.

I5 Yn chied skeeal cheayll mee moghree Laa Innid dy row my ghraih rish fer elley poost.

Dy row my villey er y doodee as mee sooree urree rish whilleen laa. Tra honnick ee nagh row graih eck orrym oddagh ee v'er n'obbal traa.

Cha jinnym jeeish drogh-loo ny gweeghyn cha wishym drogh fortçhan dy heet ny raad. Agh dy jean ee boggey da e caarjyn ge dy vel ee er yannoo jeem's agh craid.

Yn billey walnut nagh ren rieau taggloo feanish arragh cha row aym. Nish ta my ghraih er phrowal dy foalsey as ta mee faagit my lomarcan. 
VIII

hems rom $\varepsilon$ ð ðə ən i:l'perək

dreðəm mi hi:n' mər skoləg $\varepsilon: g$ er'bi:

hem fayə mə yrai os me:dn ə vargi

ha l'igəm orəm də ve:yəm i:

IX

bi:ms ðə ha:ðu os k'jodn ə vargi

jaums mə rœi d'zə'nع:n nə үع:

ax i: to pu:s rïz o moltir folsa

ha vəði kundrə ni: kax'le:

$\mathrm{X}$

in re:d mwü:ər l'jauər vəem də hju:1 er pðən oxtax ji:rax də jinu mi ski: ha voðəm səi $\int \mathrm{i}: \mathrm{s}$ də yoal' mə ' $\varepsilon: \int$ na bin $\mathrm{k}^{\mathrm{v} i} \mathrm{nd}^{\prime} \mathrm{zax} \mathrm{sm}: \mathrm{n}^{\prime} \mathrm{jax}$ er grai mə xri:

\section{XI}

o: ðə d'zinax ən gy wüər $\int e:^{1} d ə$ də vonf klaftən wif mə yrai

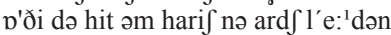
vi:dax Jin axel'ə er t'fœu ən trai

\section{XII}

sgen'al sgen'al harin də ve'de:l'i as fəs ve $\varepsilon \mathrm{m}$ də 're: mə yrai vex odn o: sgen'al sgen'al həin fi:s l'u:ri as mə ri sən pillar ek fo ə k'jodn

\section{XIII}

o: də d'zinax ən kydn mwü:ər t' 'irmax re:d ðə jinu də derin tru: ${ }^{1} \mathrm{~d}$

fn'jaxtə gri:nlən $\varepsilon: ð ə s$ d'zarg mər ro:zən rofmə nəðəm mə yrai ja'ru:d
Hem's roym er dy[s] yn 'Eaill Perrick

30 dressym mee hene myr scollag aeg erbee Hem shaghey my ghraih ayns mean y vargee cha Ihiggym orrym dy vaikym ee.

Beeym's dy hassoo ayns kione y vargee yioym's my reih jeh unnane ny ghaa.

35 Agh ee ta poost rish e molteyr foalsey cha vod ee coonrey ny caghlaa.

Yn raad mooar liauyr v'aym dy hooyll er as yn ughtagh yeeragh dy yannoo mee skee cha voddym soie sheese dy ghoaill m'aash nagh beign kinjagh smooinaght er graih my chree.

\begin{abstract}
O dy jinnagh yn geay wooar sheidey dy voddin's clashtyn woish my ghraih as ee dy heet hym harrish ny ard-sleityn veeitagh shin y cheilley er cheu yn traie.
\end{abstract}

45 S'gennal, s'gennal harrin dy veeiteil ee as fys ve aym dy re my ghraih veagh ayn S'gennal, s'gennal hoiein sheese lioree as my roih son pillow eck fo e kione.

dy jinnagh yn keayn mooar çhirmagh

50 raad dy yannoo dy darrin trooid. Sniaghtey Greenlyn aasys jiarg myr roseyn roish my noddym my ghraih y yarrood.

[1. At the fiddlers during Christmas / was the first place I met the love of my heart / lovingly, lovingly we sat down together / and began our courting.

2. From that time to the end of seven years / my love and I often met / and she promised me with her false tongue / that she would never forsake me.

3. On the Sunday evening before Ash Wednesday / I went to see the love of my heart / She put her two hands in my two hands / that she would not marry another man but me.

4. I went my way home and my heart was happy / there was nothing causing me distress / The first news I heard on the morning of Ash Wednesday / (was) that my love was wedded to another man.

5. May my curse be on the hussie / and me courting her for many a day / When she saw she had no love for me / she could have refused me early.

6. I will not make bad curse or imprecation against her / I do not wish ill-fortune to come her way / but that she may give joy to her friends / although she has made a mockery of me.

7. The walnut tree that never did speak / no other witness did I have / Now my love has proved false / and I am left alone.

8. I shall make my way to Patrick's fair / I shall dress myself like any other 
young man / I shall pass by my love in the midst of the fair / and I shall not let on that I see her.

9. I shall stand at the head of the fair / I shall take my choice of one or two / but she who is wedded to her false deceiver / she cannot barter or change.

10. The great long road that I have to walk on / and the steep hill to make me tired / I cannot sit down to take my rest / that I would be thinking always of the love of my heart.

11. O that the great wind would blow / that I might hear from my love / and she coming to me over the high mountains / we would meet each other beside the strand.

12. Happily, happily I would come to meet her / and my knowing that it is my love who would be there / O happily, happily I would sit down beside her / and my forearm for a pillow under her head.

13. O that the great sea would dry / to make a way that I might come through / The snow of Greenland will grow red like roses / before I can forget my love].

\section{I0 FREEINAGHYN AS SNAIDYN (pins and needles) (rhyme)}

Text: No other texts known.

Tune: No tune known.

\section{FREEINAGHYN AS SNAIDYN (rhyme)}

Thomas Crebbin (1847-1935), Bradda, Rushen, 1-2 September 1930 (M/IV: 2557; HLSM/I: 400-401).

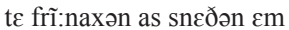
as latəon san e'n'i:n'ən as mar dzïn $\int \varepsilon d n$ fiðal að nĩmi kür 'de:u nə pĩyən
Ta freeinaghyn as snaidyn aym as laatchyn son inneenyn As my jean (sic) shen fiddal ad nee mee cur daue ny pingyn.

[I have pins and needles / and laces for girls / and if they will weave them / I shall give them the pennies].

\section{I I GOLL DY SCHOILL (going to school) (rhyme)}

Text: C'red oo goll (where are you going?) (Roeder 1896: 178).

Tune: No tune known.

GOLL DY SCHOILL (rhyme)

William Cowley (1842-1921), Creggan, Sulby Glen, Lezayre, 6 August 1909 (V/1088; HLSM/I: 316-319).

va kiət də rau va dənjə 'sö:r gol erə ra:d as vit e skəlag 'veg ðə 'gŭlə, as vrai i dłen

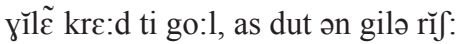

Va keayrt dy row va dooinney seyr goll er y raad as veeit eh scollag veg dy guilley, as vrie eh jeh'n ghuilley c'raad t'eh goll, as dooyrt yn guilley rish: 


\author{
gol ðə 'sko'1' \\ as vrai dze: \\ krö:d vən 'ljp:ə \\ as dǒ:t i rif \\ ซnsən 'drp:ə \\ as vra:i i dzi: \\ krö:d tan 'dro:ə \\ as dŏt i 'rif \\ onsən 'ta:i \\ as 'krö:d tən 'ta:i \\ onsən 'va:xə \\ as 'kre.d tan 'va:xə \\ onsən slju: \\ as kræ:d tan 'slju: \\ onsən 'vo:l ve rju:
}

\author{
Goll dy schoill \\ as vrie eh jeh \\ c'raad va'n lioar \\ as dooyrt eh rish \\ ayns yn drawer \\ as vrie eh jeh \\ c'raad ta'n drawer \\ as dooyrt eh rish \\ ayns $y$ thie \\ as c'raad ta'n thie? \\ ayns yn vagher \\ as c'raad ta'n vagher \\ ayns yn slieau \\ as c'raad ta'n slieau \\ ayns yn voayl v'eh rieau.
}

[Once there was a gentleman going along the road and he met a young strap of a lad, and he asked the lad where he was going, and the lad said to him: Going to school / and he asked him / where was the book / and he said to him / in the drawer / and he asked him /and where is the drawer / and he said to him / in the house / and where is the house / in the field / and where is the field / on the mountain / and where is the mountain / in the place it ever was].

\section{I 2 GRAIH MY CHREE (love of my heart) (song frag.)}

\section{Texts: Oral versions:}

1. Harry Kelly, Cregneash, Rushen, 28 January 1933 (M/III: 1917-1918).

2.Tommy Leece, Kerroomooar, Kerrookeil, Malew, Christmas/New Year 19501951 (Jackson 1955: 135-136). See also below.

Printed texts: J. R. Moore MNHL MS 09495 1st. ent. Graih my Chree ta ayns Ballaragh (love of my heart who is in Ballaragh), Moore (1896: 120 Thomas Crellin, Peel, 1st. ent. O Graih my chree, O vel oo marym? (O love of my heart, Oh, are you with me?)).

Tune: No tune known. But see under Ec ny Fiddleryn above.

GRAIH MY CHREE (song frag.).

Harry Kelly (1852-1935), Cregneash, Rushen, 28 January 1933 (M/III: 19171918; HLSM/I: 330-331).

gre:i mo 'xri: vel grei $\varepsilon ठ$ 'orəm te red 'beg a 'nel mi 'faləm wu red 'beg hejk red 'mu:r as wu ' ' $\varepsilon d n$ hejk grei ðə 'lju:r
Graih my chree, vel graih ayd orrym

t'eh red beg, cha nel mee follym

Woish red beg haink red mooar

as woish shen haink graih dy liooar.

[Love of my heart, have you love for me / It is a small thing, I am not devoid (of it) / From something small came something big / and from that there came love in abundance]. 
GRAIH MY CHREE (song frag.).

Tommy Leece (1859-1956), Kerroomooar, Kerrookeil, Malew, 9 October 1952 (YCG/32; HLSM/I: 374-375).

grei dze mə xri: vel grei ed prom t $\varepsilon$ rid beg ha nel $\varepsilon$ foləm wu rid beg hig rid mu:r az wu frid mu:r hig grei dı l'u:r

\author{
Graih jeh my chree, vel graih ayd orrym \\ t'eh red beg, cha nel eh follym \\ woish red beg hig red mooar \\ as woish red mooar hig graih dy liooar.
}

[Love of my heart, have you love for me / It is a small thing, it is not void / From a small thing something big will come / and from something big there will come love in abundance].

\title{
2. I 3 GUBBYLYN (clobber) (rhyme)
}

Text: No other text known.

Tune: No tune known.

\section{GUBBYLYN (rhyme)}

Thomas Crebbin (1847-1935), Bradda RU, 1-2 September 1930 (M/IV: 2557; HLSM/I: 400-401).

l'ig dũn'sci si:s ə'so:

as kür ən g' oblən orən' $\varepsilon g$ l'$^{\prime} \varepsilon z j \partial^{r}$ son $t \varepsilon$ a: ${ }^{r g}$ əd ə's $ə$ : ðə bi: kwpi ən dün'ə n'i: kür 'a:sa
Lhig dooin soie seese $[\mathrm{sic}]^{40}$ ayns shoh as cur yn gubbylyn orrin ec leisure son ta argid ayns shoh dy bee quoi yn dooinney nee cur ass eh.

[Let us sit down here / and put on our clobber at leisure / for there is money here whoever is the person who shall give it out].

\section{14 HIE SON SKYLLEY BREESHEY (Hi for Kirk Bride) (song frag.)}

Text: manuscript versions McLagan Manuscript 180, c. 1770, 4st., in hand of Rev. Philip Moore (1705-1783) MNHL MS 5382A (Thomson 1961: 19-20); A.W. Moore Coll: 14f, 2st. (from Robert Gawne MSS), MNHL MS 00221A.

Tune: Moore (1896: 264 from Mona Melodies (1820: 14-15). Moore (1896: xxix) supplies only the first verse of this song for the sake of the tune, 'the adventures of the party referred to being described in the rest of the ballad in language too coarse for publication. ${ }^{41}$

40 A Rushen pronunciation of Mx sheese (G sios), cf. HLSM/II: 395 v.s. sheese.

41 The version Moore gives in his ms. (MNHL MS 00221A) runs as follows: 1. Hy son Skill y Breeshey / As Hy son Skill andrase / Jurby cosney yn Dhounsyn / dy rosh ad ooilloo er keagh. 2. As quei yn shaght vun / Charles Moore (a poet) Balla Ratler as Kerry Clugaaish / As Arthur Beg Brew .... / As heie Clark wish Dhoolish [1. Hi for Kirk Bride / and hi for Kirk Andreas / Jurby to win the dances / (and) that they all got drunk. 2. Charles Moore Ballaratcliffe and Kerry Clucas / And Arthur Beg Brew / And Heie Clark from Douglas]. Evidently Moore could not make any sense of the text, as he 
HIE SON SKYLLEY BREESHEY (song frag.).

John Cain (1850-1939), Ballamoar, Jurby, 2 February 1933 (M/IV: 2625; HLSM/I: 312-315).

I

hai sən skilə bri:zə

as hai sən skjen (sic) an'dre:s

ðə jïrəbi as ka:slən (sic) döunlə

as hpi ad ðə gəl kö:x

II

ðə kre: bwi: əs skjєn an'dre:s

as ba:skad wi: o:s jö:rbi

as ro:zən d]๕g ซs bala'la:

as meftəli ซs sölbi

III

sadlər mu:r nə köl’ə

bi prə'ffe:l' sən hwil'on bl'e:dn'

a røu fad 'Egə dus mə'l'i:ənə

ðə røu реуә эs dъ॰:x as fi:dn
Hie son Skylley Breeshey

as hie son Skyll Andreays

Dy Yurby as cosney'n daunsey

as hie ad dy goll keagh

Ta cray bwee ayns Skyll Andreays

as baskad wee ayns Yurby

as roseyn jiarg ayns Ballalaa

as meshtalee ayns Sulby

Sadler Mooar ny Kella

bee preacheil son whilleen blein

Cha row fys echey dys mleeaney

dy row peccah ayns jough as feeyn

[1. Hi for Kirk Bride / and hi for Kirk Andreas / to Jurby to win the dance / and they went to go wild.

2. There is yellow clay in Kirk Andreas / and corn marigold in Jurby / and red roses in Ballaugh / and drunkards in Sulby.

3. Sadler Mooar (Big Sadler) of the Kella ${ }^{42}$ / will be preaching for many a year /

He did not know till this year/that there was a sin in ale and wine].

\section{I 5 HOP DY NAA (Hollantide chant frag.)}

Text (Manx): Clague (1911: 26-29 from Tom Kermode, Bradda RU ent. Hop! Ta'n Oie with Eng. trans.), Moore (1896: 68, ent. Hop-Tu-Naa, various (oral), with Eng. trans.), Roeder (1896: 184-186; versions from Ramsey (Eng.), 'A Bannag from the Mull' RU (Mx), Surby RU (Mx), Port Erin RU (Mx; frag.), Ramsey (Eng.; frag.), Ballaugh (Mx; frag.), Glen Maye PA (Eng.)), Paton ([1941]: 76-82).

Text (English): Train (1845 II: 123), Harrison (1873: 148 ent. Hop-Tu-Naa).

Tune: Clague C1/49:2 Tom Kermode, Bradda, ent. Hop dy nai (Gilchrist 19241926: 174), Moore (1896: 243 I: Mrs. [Margaret Frissel] Ferrier, Castletown, II: Philip Cain ('Phillie the Desert'), Baldwin BN.

Manx Hop-dy-Naa, the name given to the last day of the Celtic year (31 October) on which children are wont to go from house to house chanting a rhyme and thereby earning sweets (nowadays money), does not appear to have any Celtic etymology.

writes 'no sense' to the right of each verse. To judge from his comments above, he had evidently obtained another version of the text, which to date has not seen the light of day.

42 '(farm of/by the) wood' (viz. Mx (balley ny) Keylley, G (baile na) coille), a farm near Sulby (SC391951), with ellipsis of the head word. 
The phrase Hop- $d y$-Naa forms a vocable chorus to the rhyme chanted, which seems to have given its name to the event, formally Sauin (G Samhain 'end of summer'), Oie Houney/i: 'houna/ (G Oidhche Shamhna 'the night of Souney/Samhna'), Eng. (Hollantide/Hallowe'en). Many customs are associated with this event.

According to Kelly 1866 v.s. Baal-Sauin,

[...]. On this night [i.e. Hollantide] [...] 'the women knead their dough to make cakes to the Queen of Heaven' [...]. Much ceremony is observed in making this cake, which is sacred to love [...] and is called the 'soddag valloo' or dumb cake. Every woman is obliged to assist in mixing the ingredients, kneading the dough and baking the cake on glowing embers; and when sufficiently baked they divide it, eat it up, and retire to their beds backwards without speaking, from which silence the cake derives its name, and in the course of the night expect to see the images of the men who are destined to be their husbands [...] (Kelly 1866 v.s. Baal-Sauin, quoted also in Paton [1941]: 76).

Moore (1891: 125), in quoting the above, adds that the ingredients included 'flour, eggs and egg-shells, soot, \&c.' For further details see Moore (1891: 122125), Clague (1911: 23-31), Paton ([1941]: 76), Gilchrist (1924-26: 174-177).

Karl Roeder (1904: 17), a native of Gera, Thüringen, but then resident in Manchester, notes the following custom associated with Hop dy Naa:

On Holy Eve the girls used to go at 12 o'clock at night and carry a ball of woollen yarn in their hand, and steal to a barn without anyone knowing anything about it, and twisting the end of it round their wrist threw the ball in the darkness as far as they could; then after a little while they began to wind it up, beginning at the end twined around their wrist. If the thread was held they would cry out [in Manx]: 'Who is holding the thread?' and they expected whoever held it to say who he was; if there was no answer they were to be old maids (Roeder: 1904: 17, quoted also in Paton: [1941]: 77).

HOP DY NAA (chant frag.).

William Killip (1834-1922), Clyeen, Michael, 3 August 1890 (Rhŷs 6/95). ${ }^{43}$

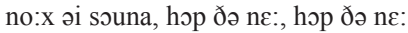

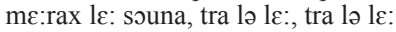

Noght Oie Houney, Hop dy Naa, Hop dy Naa mairagh Laa Souney, tra lal laa, tra lal laa.

[Tonight is Oie Houney, Hop dy Naa, Hop dy Naa / tomorrow is Laa Souney, tra lal laa, tra lal laa].

HOP DY NAA (chant frag.).

43 Rhŷs provides only the phonetic versions of his texts. The versions in Standard Manx Orthography, here as elsewhere, are supplied for convenience. 
John Kermode (1811-1891), Surby, Rushen, 7 August 1890 (Rhŷs 6/105)

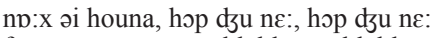
famən nə gouna, tral lal le:, tral lal le: kjalax nə kiarkən, həp dзu ne: \&c.
Noght Oie Houney, Hop Tu Naa

famman ny gouney, tra lal laa kellagh ny kiarkyn, Hop Tu Naa.

[Tonight is Oie Houney... / tail of the heifer.../ cock or hens...]

HOP DY NAA (chant frag.).

William Corrin (1817-1892), Cronk y Doonee, Rushen, 8 August 1890 (Rhŷs 6/113).

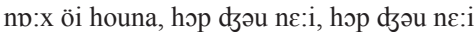
Jivər nə gəuna, hop dzəu ne:i, həp dzəu ne:i kən go:n marmad, həp dzəu ne:i, həp dzəu ne:i go:n spo:dax brek, həp dzəu ne:i, həp dəəu ne:i
Noght Oie Houney, Hop Tu Naa shibbyr ny gouney, Hop Tu Naa cre'n gouin marmayd, Hop Tu Naa gouin spottagh breck, Hop Tu Naa.

[Tonight is Oie Houney... / supper of/for the heifer... / what heifer shall we kill... / a speckled spotted heifer...].

HOP DY NAA (chant frag.).

'Paaie Vooar' (Mrs. Margaret Taylor (1816-1890), Surby, Rushen, 8 August 1890 (Rhŷs 6/117-118).

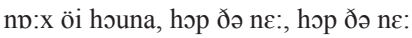

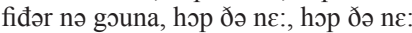

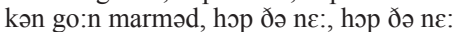

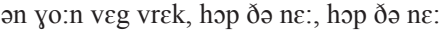
kən keru verməd sə fət dze:,

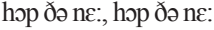

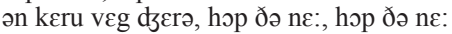

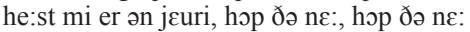

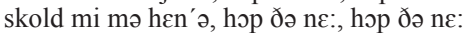

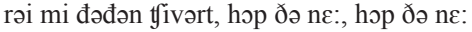

\author{
Noght Oie Houney, Hop dy Naa \\ fidder ny gouney, Hop dy Naa \\ cre'n gouin marmayd, Hop dy Naa \\ yn ghouin veg vreck, Hop dy Naa. \\ cre'n kerroo vermayd sy phot jeh, \\ Hop dy Naa, Hop dy Naa \\ yn kerroo veg jerrey, Hop dy Naa \\ haste mee er yn awree, Hop dy Naa \\ scauld mee my hengey, Hop dy Naa \\ roie mee dys yn çhibbyrt, Hop dy Naa.
}

[Tonight is Oie Houney... / weaver of/for the heifer... / what heifer shall we kill.../ the little speckled heifer... / what quarter shall we put in the pot... / the wee end quarter... / I tasted the broth... / I scalded my tongue... / I ran to the well...].

\section{I 6 HUDGEONY FIDDER (Hudson the weaver) (song frag.)}

Text: Moore (1896: 212 from Prof. John Rhŷs).

Tune: No tune known. 
Moore (1896: xxix) notes: 'Hudgeon y Fidder (Hudgeon [Hudson] the weaver) is the only [known] song which gives an intimation that there was once such a thing as smuggling in the Island.'

HUDGEON Y FIDDER (song frag.).

John Carrine (1824-1893), Chasm House, Cregneash, Rushen, 14 August 1892 (Rhŷs 6/189).

'At Fleshwick an old Manxman called Carin Hurbi (Carine of Surby) who showed us into a cave repeated to me the beginning of a ballad about a smuggler called [hədzin ə fiđər] (Hudgeon the Weaver). He was a fellow with very big lips -

V'eh goll seose eg y Chreg Ghoo Cha row wheesh as troggal a chione Son va daa veeall er Hyjin [hədtin] Kiart wheesh my daa ghoarn As va daa roll dy hombaga Ayns mean y vart connee. ${ }^{44}$ (dhoo is pronounced by him dū [du:]) (pr. [tro:l] and [ $\left.x^{\prime} j o d n\right]$ )

(the $\underline{r}$ was scarcely to be heard) $\left(? \mathrm{as}^{\frac{45}{5}}\right)$

[He was going up at the Black Rock / he was not so much as lifting his head / for there were two lips on Hudgeon / just as big as my two fists / and there were two rolls of tobacco / in the middle of his load of gorse].

There was more of this stuff and it used to be sung, as Hyjin [Hudgeon] seems to have been a noted character in these parts' (Rhŷs 6/189).

HUDGEON Y FIDDER (song frag.).

William Collister (18??-18??), c/o of Edward Collister, 9-16 August $1892^{46}$ (Rhŷs $5 / 8 b)$.

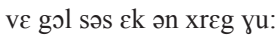

ha rou hwi: $\int$ as tro:al $ə \mathrm{x}^{\prime} \mathrm{j}$ jodn son va đe vi:l $\varepsilon r$ hudzin

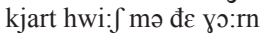
as $\mathrm{v} \varepsilon$ đ $\varepsilon$ rol đə hombaga o:ns men ə vart koni: ${ }^{47}$

V'eh goll seose ec yn Chreg Ghoo
cha row wheesh as troggal e chione
son va daa veeal er Hudgeon
kiart wheesh my daa ghoarn
as va daa roll dy hombaga
ayns mean y vart chonnee.

V'eh goll seose ec yn Chreg Ghoo son va daa veeal er Hudgeon as va daa roll dy hombaga ayns mean y vart chonnee.

[He was going up at the Black Rock / he was not so much as lifting his head /

44 As with $Y$ Maarliagh Mooar above, Moore obtained this song-fragment also from Rhŷs (Moore 1896: xxx) and prints it in his Manx Ballads (1896: 212) under the title Hudgeon y Fidder ('Hudson the weaver'), again 'correcting' the text.

45 Rhŷs's own comments.

46 Place of residence of the Collisters is to date not known, but given that they were aware of the song about Hudgeon, then probably somewhere in Rushen parish. Precise date of interview unknown.

47 For the text see also Moore (1896: 212). 
for there were two lips on Hudgeon / just as big as my two fists / and there were two rolls of tobacco / in the middle of his load of gorse].

\section{I 7 JUAN GAWNE (rhyme)}

Text: No other text known.

Tune: No tune known.

JUAN GAWNE (rhyme)

Mrs. Annie Kneale (1864-1949), Ballagarrett, Bride, 1948 (IFC/39; HLSM/I: 306-307).

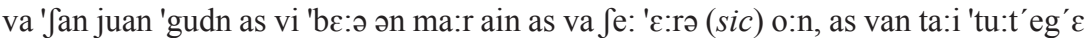
as va ko:gi house 'tu:t' as va bə:l dən.., rïfən 'ka:bəl beg as ən 'bu:ə, as vi 'fi: sən 'bö:aa, as vi 'gre: - kokə 'kok, as then vi 'gre:

Va shenn Yuan Gawne as v'eh baghey yn magher ain as va shey ?acyr ayn, as va'n thie thooit as va coigee house thooit as va boayl da'n...rish yn cabbyl beg as yn booa, as v'eh fee son baghey, as v'eh gra, 'Cockacock', as then v'eh gra:

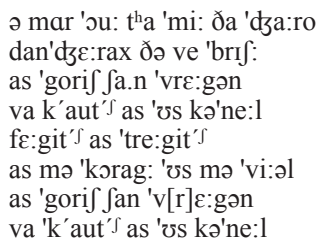

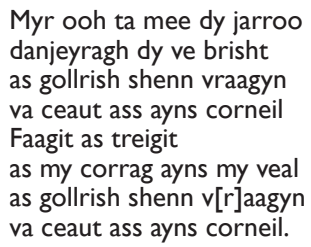

[There was old Juan Gawne and he was living (in) our field and there were six acres in it, and he had a thatched house and a thatched loom house, and there was a place for the small horse and the cow, and he was weaving for a living, and he used to say, 'Cockacock', and then he would say:

Like an egg I am indeed / in danger of being broken / and like old shoes / that were worn out and (thrown) in a corner / left and abandoned / and my forefinger in my mouth / and like old shoes / that were worn out and (thrown) in a corner].

\section{I8 KIARK KATREENEY MARROO (Catherine's hen is dead) (chant)}

Text: Clague Bk 5: 48, Moore (1896: 68 from Moore 1891: 127). Tune: Moore (1896: 227 John Bridson, Colby AR).

With regard to the custom, Moore (1891: 126-127) makes the following comment:

December 6th-Laa'l Catreeney (Catherine's feast-day) (old style). On or about this day possession must be taken on the South side of the Island of lands, 
when there is a change of occupier. A fair was held on this day in the Parish of Arbory, when the following curious distich was repeated.

Kiark Catreeney marroo,

Gow's y kione,

As yoyms ny cassyn,

As ver mayd ee fo'n thalloo.
Catherine's hen is dead,

Take thou the head,

And I will take the feet,

And we will put her underground.

(Moore 189|: |26-127).

Clague (1911: 43-45) supplies further details:

[...] [B]efore there were any attorneys, the people of Colby Mooar put aside all their fallings out that were between them at the feast of St. Katherine, and that each party would peel (pluck) some of the feathers [from a hen] and bury them, and the case was settled.

I have heard an old man say that his mother kept a public-house, and she had told him that the men and young boys of the neighbourhood would kill a hen, and they would walk two and two, holding the hen between them, and other persons would walk two and two through the fair with their hats off, as if they would be at a funeral, and sing,

Kiark Katreeney marroo

Gow uss y kione, as goym's ny cassyn

as ver mayd ee fo halloo

They would then go to the public-house and get plenty of ale.

A wake was kept (held) over the hen, and early the next day the men went to 'peel the hen.' The head and the feet were cut off, and they were buried. It gave them an opportunity to get a little drop on the next day. Anyone who went to the public-house (tavern) on the day after the fair, people said, 'He is going to peel the hen.'

Moore (1896: xxi) has:

The quaint distich Kiark Katreeney Marroo 'Katherine's hen is dead' was formerly sung at a fair held on the 6th of December, this being Laa'l Katreeney 'Katherine's Feast Day' at Colby, in the parish of Arbory. Those who sang it got possession of a hen which they killed and plucked, and, after carrying it about, buried. If any one got drunk at the fair it was said T'eh er goaill fedjag ass $y$ chiark 'He has plucked a feather from the hen' (Moore 1896: xxi).

KIARK KATREENEY MARROO (chant).

Capt. Henry Watterson (1816-1894), Colby, Rushen, 18 September 1888 (Rhŷs 6/21). 
A Fair is [mar' ge/mer' ge] St. Catherine's fair at Colby used to be held on the 6th of December and will be again probably (there is a lawsuit about the feild [sic] for holding it) and it began with a procession in which a live hen was carried about (and probably killed) and ended (?next day?) by the hen being carried about plucked and dead. A rhyme was used then to the following effect:

Kiark Catr[i:]na 'marroo

Dous/Gows yn [kjon] as goms ny cassyn ([kazən])

As vermayd ([ve:rmadi] $)$ ee fo'n thalloo (Rhŷs 6/21).

[Catherine's hen is dead, you take the head and I shall take the feet / and we shall put her under the ground].

KIARK KATREENEY MARROO (chant).

Edward Faragher, Sr. (1803-1890), Cregneash, Rushen, 18 September 1888 (Rhŷs 6/24).

kjarg ka'tri:na maru, gous a kjodn as goms nə kazən as vermad i fon $\mathrm{t}^{\mathrm{h}}$ alu
Kiark Katreeney marroo gow uss y kione as gowym's ny cassyn as vermayd ee fo'n thalloo.

[Catherine's hen is dead, you take the head and I shall take the feet / and we shall put her under the ground].

\section{19 LHIGEY, LHARGEY (galloping, galloping) (children's rhyme)}

Text: MNHL MS 00221A/20 (A. W. Moore Coll.) (1 st.) ent. 'The Red Petticoats,' ${ }^{48}$ Moore (1896: 216-217). According to Moore (1896: xx), he received this rhyme from Miss Elizabeth Jane Graves (1851-1931), Peel, who collected song material for A. W. Moore during the 1890s (Miller Manx Notes 2017/4: 14-15). Moore (ibid.) adds, that ' $[\mathrm{t}]$ he girls when playing it kneel on the ground on one knee, and strike the other knee with their right hands as they say each word.'

Tune: No tune recorded as the rhyme was spoken.

LHIGEY, LHARGEY (children's rhyme).

Ned Maddrell (1877-1974), Glenchass, Rushen, April / May 1948 (IFC40; HLSM/I: 368-369).

48 Text: Ah heu my mothee beg goll gys y kiel / Cockal y famman er mullach y kys / Drib drab fud ny laghey / Geirt er ny mraane less ny unraghyn jeargey [Ahoi my wee dog going to the church / cocking its tail on the top of its buttock / Drib drab through the mud / going after the women with the red petticoats] MNHL MS 00221A/20 (A. W. Moore Coll.) 
ljigə ljö:gə gəl gəs ə vö: ${ }^{\mathrm{rg}} \mathrm{g}$

göit'er nə mre:n l'eş nə ซndrayən dzö:rgə

ljigə ljö:gə gol gəs ə ki:1

gait' $\varepsilon$ nə mre:n l'eş nə ซn'drayən gri:dn
Lhigey, Ihargey, goll gys y vargey

geiyrt er ny mraane lesh ny

oanraghyn jiargey

Lhigey, lhargey, goll gys y keeill geiyrt er ny mraane lesh ny oanraghyn green.

[Galloping, galloping, going to the fair / following the women with the red petticoats / galloping, galloping, going to the church / following the women with the green petticoats].

\subsection{MANNIN VEG VEEN (dear wee (Isle of) Man) (song frag.)}

Text: manuscript versions: Fourteen stanzas taken down by Rev. J. T. Clarke from a recitation by Harry Quilliam, Peel (i.e. Harry Jack, Cronk Mona, Dalby) 'on December 15th 1868', according to MNHL MS unacc. (Clarke) for Harrison 1873: 136. Clague Bk. 3: 276 frag. 1st stanza beg. Ayns thie Quiggin Vooar (in Big Quiggin's (ale-)house) with Eng. trans., MTSSF/II: 26-27 (Bk. 16: 38, 147), 5st. Printed versions: Broadside of above text by J. C. Faragher, Douglas, c. 1870 (14st. + Eng. trans.), Moore (1896: 176 from Harrison 1873).

Tune: MNHL MS unacc. (supra) 'to the tune of Barbara Allen'; Clague C2/13:1 and C3/3: 5 informants unknown, both ent. 'In 1823 and March 23rd [day]', the latter also ent. Hug shin seose y shiaull mean (we hoisted the main-sail); cf. the line st. 4 Eisht hrog shin shiaull erskyn nyn gione (then we hoisted the sail above us, lit. 'our heads'). For the tune to Barbary Allen see Moore (1896: 242 Thomas Crellin, Peel). Below are the first and second stanzas respectively.

The song tells of the experiences of the Peel fishermen on their way to the herring fishing off the Calf of Man, and all ending up in Douglas in a local hostelry to celebrate the end of the herring season (September). ${ }^{49}$

MANNIN VEG VEEN (song frag.).

John Cannon (1815-?1893), Ballaugh, 15 July 1893 (Rhŷs 7/196).

manin veg vi:dn, ta uns mẽ:n y xiədn ta unzi weit jes'ti:rən
Mannin Veg Veen, ta ayns mean y cheayn ta aynjee weight eeasteyryn.

[Dear wee Mannin which is in the midst of the sea / in which there are lots of fishermen].

49 The Manx semi-speaker Ewan Christian (1907-1985), Peel (Broderick 2017: 48-49), told me in an interview in 1978 that he remembers Peel fishermen standing on a table in the Marine bar on Peel promenade during the 1920s and singing Mannin Veg Veen. Christian was unable to provide me with any details as to the tune, etc., other than that the song was sung with gusto. 
MANNIN VEG VEEN (song frag.).

Thomas Christian (1851-1930), Ramsey, July-September 1929 (M/II: 1237; HLSM/I: 210-211).

hi: main' rõ:n'gös ən el'õ:n'

də ḑ̧i:ən 'võ:main' skil er skaðan

Hemmain roin gys yn Eaill' Eoin

dy jeeaghyn vowmain skeeal er skaddan.

[We'll get going for St. John's Fair / to see if we'll get news of herring].

\subsection{I 'MANX FAIRY', The (rhyme)}

Text: Beale (1868: 368a) 2st., ${ }^{50}$ Radcliffe (1989: 62) 2st.

Tune: No tune known.

The 'Manx Fairy' was built in 1853 for the then newly-founded Ramsey (Isle of Man) Steam Packet Company [1830] by John Laird, Birkenhead, and sold in 1861 after a series of mishaps to Cunard, Wilson \& Co., Liverpool. The people of Ramsey were apparently very proud that Ramsey had a boat of its own. For further details see Radcliffe (1989: 62-67).

'MANX FAIRY', The (rhyme).

Thomas Christian (1850/51-1930), Ramsey, July-September 1929 (M/II: 1305-06: HLSM/I: 218-219).

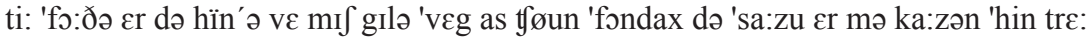

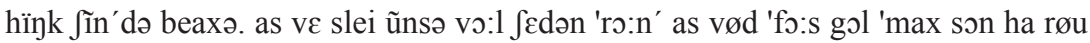

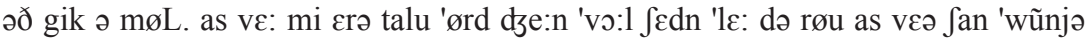

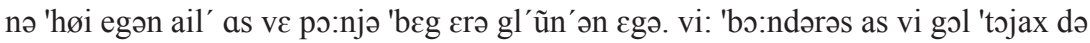

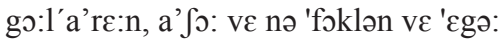

T'eh foddey er dy henney va mish guilley veg as çhionn fondagh dy shassoo er my cassyn hene tra haink shin gys Fo-slieau dy baghey. As va sleih ayns y voayl shen roin, agh v'ad foarst goll magh son cha row ad geeck y mayl. As va mee er y thalloo ard jeh'n voayl shen laa dy row as va shenn wooinney ny hoie ec yn aile, as va pohnar beg er y glioonyn echey. V'eh boandyrys as v'eh goaill toshiaght dy goaill arrane. As shoh va ny focklyn va echey:

te:n 'ferif $\varepsilon \mathrm{r}$ 'ra:ft' bunəs gøs 'sa:stən

$1^{\prime} \varepsilon \int$ nə 'hwi:l'axən tapi tføn'd $\varepsilon: \partial t$ '
Ta'n 'Ferrish' er roshtyn

bunnys gys Sostyn

lesh ny wheeylaghyn tappee çhyndaait

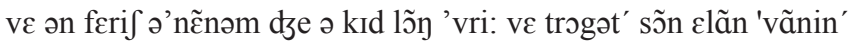

50 Printed in Miller 2019 (Manx Notes 193 (2014): 2). 
Va yn 'Ferrish' yn ennym jeh y chied lhong-vree va troggit son Ellan Vannin

[It is long since I was a wee lad and very sure of standing on my own feet when we came to Folieu ${ }^{51}$ to live. And there were people in there before us, but they had to leave as they could not pay the rent. I was on the high ground of the place one day and there was an old man sitting by the fire, and there was a wee wain sitting on his knees. He was nursing it and started to sing. These were the words he had:

The 'Fairy' has almost reached England / and the wheels (i.e. paddles) quickly turned.

The 'Fairy' was the name of the first steamship that was built for the Isle of Man].

'MANX FAIRY', The (rhyme).

John Cain (1851-1939), Ballamoar, Jurby, 2 February 1933 (M/IV: 2624; HLSM/I: 312-313).

t $\varepsilon$ ən $\mathrm{f} \varepsilon: \mathrm{ri} \int \varepsilon \mathrm{r} \mathrm{r} \int \mathrm{t}^{\prime}$ ən wuz n'i:r as $\int \varepsilon n$ sp:sən t $\varepsilon$ ən ful'on (sic) $\varepsilon \mathrm{g}$ taßi tö̈n'd $\varepsilon$ :

o: mãnən'vig vidn

t $\varepsilon$ ən $\mathrm{kri}: \varepsilon \mathrm{d} / \mathrm{v} \varepsilon \mathrm{l}$ ə xri: $\varepsilon \mathrm{d} \mathrm{tidn}$

a stil buzal mpi ðə rum'ze:
Ta yn 'Ferrish' er roshtyn woish neear-ass shenn Sostyn ta yn wheeylyn eck tappee çhyndaa O Mannin Veg Veen ta yn cree/vel y chree ayd jean as still pushal mie dy Rhumsaa.

[The 'Fairy' has arrived / from the west of old England / her wheels (paddles) are quickly turning / $\mathrm{O}$ wee Mannin dear / your heart is full of enthusiasm / and still a good push (pushing well) to Ramsey].

\subsection{MYLECHARAINE (song frag.)}

Texts: manuscript texts: McLagan MS 180 (University of Glasgow); photocopy MNHL MS 5382A (6 coupl. + addl. refr.) c. 1770 in hand of Philip Moore (17051783); BL Addl. 11215 'An Old Manks Madrigal' c. 1789 in hand of Deemster Peter John Heywood (1739-1790) (7 coupl. + addl. refr.); MNHL MD 900 MS 08307 (c. 1830-1840) (p. 2) 3st.; (p. 6) 5st.; (p. 7) (6st.); MNHL MS 2151A in hand of T. E. Brown (1830-1897) (5 coupl. 1893); ${ }^{52}$ Clague Bk 5: 48 (1st.) couplet beg.

51 'under (the) mountain', a farm on the hillside near the main Ramsey-Laxey road (SC463933).

52 MNHL MS 2151A contains 5 stanzas written on the back of a note sent to Manx poet $\mathrm{T}$. E. Brown (1830-1897) from the Ramsey Courier Office dated 26 August 1893. It is not included here, as the text derives from Harrison (1869: 57). 
O Vylecharaine, c'raad hooar oo dty stoyr (O Mylecharaine, where did you find your store?). Variants range between 1 and 14 couplets.

Printed texts: Leech (1861: 125-126; 9 coupl.); Broadside with Thomas Shimmin's name appended, M. A. Quiggin, Douglas c. 1867 (9 coupl. + Eng. trans.); MNHL MS 28A (Wm. Sayle Coll.); Cookson (1868: 187; 2 coupl.); Harrison (1869: $57-$ 58; 10 coupl.); Drennan (1870: 469 (8 coupl.)); MNHL MS 140 (Manx Language Scrapbook) pamphlet by J. C. Faragher, Douglas, c. 1870 (10 coupl.); Paton (1920: 30-39; 1 coupl.); Moore (1896: 52; 12 coupl. First 10 from Harrison (1869); last two from MD 900); Gilchrist (1924-1926: 205-206).

Oral texts: Collected in phonetic script by Prof. Carl. J. S. Marstrander, Professor of Celtic Studies in the University of Oslo, Norway, during his visits to Man (1929-1930):

1. From Thomas Taggart, Grenaby, Malew, 16 June $1929^{53}$ (M/IV: 2231-2235) (6 st.).

2. From Joseph Woodworth, Port Erin, Rushen, 28 August 1930 (M/III: 16591663) (8 st.).

Tune: MNHL J66 6523 MS 437A (Shepherd Music Coll.) c. 1815-this is the first notice of this tune. Clague C3/44: 1 John Cain [Douglas]; C4/29: 3 Eliza Cookson: 1859; C4/30: 2 Mylrea's version, C4/30: 3 Corteen's version, JFSS VII/28: 124-125; VII/29: 205, note 28; Moore (1896: 253 Henry Bridson, Cronkbourne, Tromode BN, ibid. 254; Mona Melodies 8-9); Gilchrist (1924-1926: 205-206) with discussion.

With regard to the content of the song, Thomson (1961: 12) notes:

The poem purports to refer to one Mylecharaine, who lived in or near the Curragh in Jurby [SC3696] in the north-west of the island, and who was supposed to have earned general execration by being the first Manxman to give his daughter a dowry instead of expecting a bride-price for her. The name, to judge from the earliest spellings, represents [G] Mac Ghille Chiaráin rather than Maol Chiaráin; the second element, however, had become identical with the common noun carrane (G cuarán), a shoe or sandal made of untanned hide, often with the hair on it, and this may have given particular point to the mention of his footwear in the course of mocking his parsimonious habits (Thomson 1961: 12).

53 Marstrander visited Taggart for the first time on 16 June 1929 (Dagbok 16) when presumably he obtained a version of Mylecharaine from him, as in collecting a (similar) version of the song from Joseph Woodworth on 28 August 1930, Marstrander cites two variants he had obtained from Thomas Taggart (MIII: 1659-1663). Marstrander visited Taggart for the last time on 27 September 1930 (MIV: 2207b-2483). 
For a discussion and analysis of the text, see Thomson (1961: 10-18), Broderick (forthcoming b). As with Ny Kirree fo Niaghtey (below), this became one of the most renowned traditional songs in the Manx repertoire.

The name Mylecharaine is the Manx reflex of Gaelic mac giolla Chiaráin.

MYLECHARAINE (song frag.) [moləka're:n]

Thomas Taggart (1846-1933), Grenaby, Malew, 16 June 1929 (M/IV: 2231-2235)

I

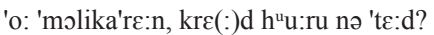

as nə lomarkən de:gu mi

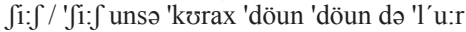

spn nə lrmarkən de:g e mi

II

'o: 'molika're:n, kre(:)d hüu:ru nə 'te:d?

nə du:r mi sə 'kurax e $\varepsilon ð ə r$ 'd $\varepsilon:$ ' $\varepsilon: \mathrm{d}$

III

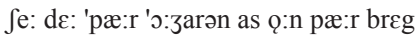

væ $\varepsilon k$ moləka're:n

IV

'o: jezək o: jezək 'tæ: mi go:l'nę:rə

də velu gəl gəsə 'ki:1' 1' $\varepsilon \int$ də ka're:nən grę:nə

V

'o: vซði, 'o: 'vซði ha 'l'as döts gǫ:1' 'nę:rə

son tæ: cməs uns 'k'ǫ.h ə kǫ:r verə ə:rts də 'g' ę:rə

VI

ax mə volaxt, mə volaxt $\varepsilon$ r moləka're:n

spn væ ən k'єd dซn'ə hซg 'ta:r də mə'ren
O Mylecharaine, c'raad hooar oo ny t'ayd? as ny lomarkan daag oo mee

Sheesh ayns y curragh dowin, dowin dy liooar son ny lomarkan daag eh mee.

O Mylecharaine, c'raad hooar ny t'ayd?

Nagh dooar mee sy curragh eh eddyr daa aaid

She daa piyr oashyryn as un piyr brag va ec Mylecharaine ayns hoght bleeaney as feed

$O$ yishag, $O$ yishag, ta mish goaill nearey dy vel oo goll gys y keeill lesh dty carraneyn graney

O vuddee, $O$ vuddee, cha lhiass dhyts goaill nearey son ta aym's ayns kione $y$ koir ${ }^{54}$ ver eh orts dy gearey

Agh my vollaght, my vollaght er Mylecharaine son v'eh yn chied dooinney hug toghyr da mraane

[1. O Mylecharaine, where did you get what you have / and alone you did leave me / down, down in the curragh, deep, deep enough / for alone you did leave me.

2. O Mylecharaine, where did you get what you have / Did I not find it in the curragh between two turf-sods.

3. It is two pairs of stockings and one pair of shoes / which Mylecharaine had in twenty-eight years.

4. O father, O father, I am ashamed / that you go to church in your ugly sandals. 5. O girl, O girl, you have no need to be ashamed / for I have in Kione y Koir that which will make you laugh.

6. But my curse, my curse on Mylecharaine / for he was the first man who gave a dowry to women].

54 LN ?coan (n)y koir 'hollow of the chest(stone)'. 
MYLECHARAINE (song frag.).

Joseph Woodworth (1853-1931), Port Erin, Rushen, 21 August 1930 (M/III: 1659-1663).

I

'o: 'vplikə're.h, kred 'hu:ru də 'stǫ:r ? mə 'lomaxən 'd $\varepsilon$ : yu mi væ hi:s unsnə (sic) körax 'dəun də 'l'u:r as mə 'lomaxən 'd $\varepsilon$ :yu mi

II

'o: 'vplikə're:h kre:d 'hu:ru nə 'stok ? hi:s unsnə (sic) korax öðə de: vlpk

III

'o: vplikə're.h kre:d 'hu:ru ne 'teð ?

hi:s unsnə (sic) kurax öðər de: fọ:d'

IV

fe: de: 'fæ:r 'p:zərən as õ:n pæ:r 'vreg

væ $\varepsilon$ molikb're.h uns 'fe: 'bl'i:nə as 'fid'

V

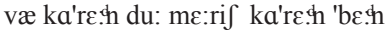

as 'pæ:r ḑe: ən ǫ:n xolər $\varepsilon k$ dulif ḑe'sarn

VI

'o: jizəg, 'o: jizəg, tæ mi go:1' 'nę:ra

də 'velu gol dəsnə (sic) ki:1 l'e $\varepsilon$ də ka're.hən 'grę:na

VII

'o: i'n'i:n mə 'xri: 'a 'l'as döt go:l' 'ne:rə

spn 'tæ: $\varepsilon^{b}$ m uns k'ọ!h a kö:r as n'i: kör 'prts ge:rə

VIII

ax mə vplax, mə vplax عr voləka're.h

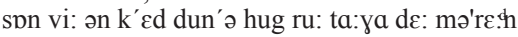

OVylecharaine, c'raad hooar oo dty stoyr? my lomarcan daag oo mee

V'eh heese ayns y curragh dowin dy liooar as my lomarcan daag oo mee.

OVylecharaine, c'raad hooar oo ny stock? Heese ayns y curragh eddyr daa vlock.

OVylecharaine, c'raad hooar oo ny t'ayd? Heese ayns y curragh eddyr daa foaid.

She daa phiyr oashyryn as un phiyr vraag va ec Mylecharaine ayns shey bleeaney as feed.

Va carrane dhoo mârish carrane bane as piyr jeh yn un chullyr ec Doolish Jesarn.

$O$ yishag, $O$ yishag, ta mee goaill nearey dy vel oo goll dys y keeill lesh dty carraneyn graney.

O inneen my chree, cha lhiass dhyt goaill nearey son ta aym ayns kione y koir $^{55}$ as nee cur orts gearey.

Agh my vollagh, my vollagh erVylecharaine son v'eh yn chied dooinney hug rieau toghyr da mraane.

[1. O Mylecharaine, where did you get your store / alone you did leave me / It was in the curragh deep enough / and alone you did leave me.

2. O Mylecharaine, where did you get your stock / Down in the curragh between two blocks (of stone).

3. O Mylecharaine, where did you get what you have / Down in the curragh between two turf sods.

4. It is two pairs of stockings and one pair of shoes / which Mylecharaine had in twenty-six years.

5. There was one black sandal with a white sandal / and two of the same colour when in Douglas of a Saturday.

55 'end of the chest', a place name seemingly in Jurby Curragh (SC3696). Or perhaps for coan (n)y koir ('hollow of the chest(stone)')? For this see under Ny Kirree fo Niaghtey (\$2.25) below. 
6. O father, O father, I am ashamed / that you go to church in your ugly sandals.

7. O daughter of my heart, you have no need to be ashamed / for I have in Kione y Koir that which will make you laugh.

8. But my curse, my curse on Mylecharaine / for he was the first man who gave a dowry to women].

\subsection{MYR S'LIAUYRYN OIE-GEUREE (how the winter night is long) (song frag.)}

Text: This is a version of Arrane Sooree (courting song), cf. MD 900 (c. 18301840): 19 ent. Mor s'lauyr vah nee geurey buoy (how the winter's night was long, boy) (3st, 2 half-stanzas), MD 900 19-20 no title, 7st. + part st. MNHL MD 900 MS 08307; Clague Bk 5: 94-98 (11st.), text identical with that in Moore (1896: 80-81). Also JFSS VII/28: 135-136, 29: 209-210, 30: 322 note.

Tune: Version A: Clague C1/19: 3 Mrs. Lawson, Jurby East JU. Version B: C1/22: 3 informant unknown (variant of 'As I went out one morning clear' C1/7: 1); C4/25: 1 John Quayle, Gordon PA, and Moore (1896: 234 John Quayle, Glen Maye PA (likely the same person; Miller (Manx Notes 2017/8: 9)). Latter two are variants of Tune B. All versions in Clague entitled Sooree.

MYR S'LIAUYR YN OIE-GEUREE (song frag.).

William Cowley (1842-1921), Creggan, Sulby Glen, Lezayre, 6 August 1909 (in Douglas) (V/1088; HLSM/I: 316-317).

\author{
ma 'sl'auər ən æi 'gjeu[ri] \\ ma 'stoli i də ' $k$ ' au \\ va mi nə 'ha:ðu ek ən dorəs \\ as mi ซlju go:l $\varepsilon$ : 'kre:u: \\ mə 've:ə va gorif 'latən \\ as mə fi:klən snagəri: \\ as mə grai tro ${ }^{b} \mathrm{~m}$ nə 'kadle \\ ha 'rau i kla: $\mathrm{tt}^{\prime}$ on mi: \\ hog mi 'frap $\varepsilon$ :rən 'nənjag \\ as snip $\varepsilon: r ə$ 'rle:s \\ as mə 'kri: 1'ibm mar 'əzag \\ tहu 'sta:i dze: mə 'vres \\ as mə 'grai as mə 'grai \\ hed main 'kodzax 'nv:x nə 'jæ:i
}

\author{
Myr s'liauyr yn oie geu[ree] \\ myr s'doillee ee dy ceau \\ va mee ny hassoo ec yn dorrys \\ as mee ooilley goll er-creau \\ My veir va gollrish lattyn \\ as ny feeacklyn snaggeree \\ as my graih trome ny cadley \\ cha row ee clashtyn mee \\ Hug mee frapp er yn uinnag \\ as snip er $y$ ghless \\ as my cree lheim myr ushag \\ çheu-sthie jeh my vreast \\ as my graih, as my graih \\ hed main cooidjagh noght ny yeih.
}

[How the winter night is long / how it is difficult to spend it / I would be standing at the door / and I would be all a-tremble / My fingers would be like lats and my teeth chattering / and my love sound asleep / she would not be hearing me / I tapped on the window / and knocked on the glass / and my heart would be leaping like a bird / inside my breast / And my love, and my love / we shall go together tonight after all].

\subsection{NANE JEES, MYLECHREEST (one two, Mylechreest) (children's rhyme)}

Text: No other text known.

Tune: No tune known. 
NANE JEES, MYLECHREEST (children's rhyme) John Cain (1850-1939), Ballamoar, Jurby, 2 February 1933 (M/IV: 2633; HSLM/I: 312-313).

$$
\begin{aligned}
& \text { ne:n dzi:s 'molə kri:s } \\
& \text { tri: } k^{\prime} e^{\text {r }} \text { beti ve:r } \\
& \text { kweg fe: bïl nə kl'e: } \\
& \text { fa:x ho:x tom ə lp:x } \\
& \text { nei dzei tomi fei }
\end{aligned}
$$

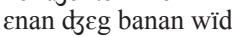

\author{
Nane, jees, Mylechreest \\ Tree, kiare, Betty Vayr \\ Queig, shey, Bill ny Cleigh \\ Shiaght, hoght, Tom y Logh \\ Ney, jeih, Tommy Faaie \\ Annan jeig, ben yn woid.
}

[One two Mylechreest / three four Betty Vayr (of the road) / five six Bill ny Clay (of the hedge) / seven eight Tom y Logh (of the lake/swamp) / nine ten Tommy Faaie (of the flatt) / eleven, woman of the penis].

\subsection{NY KIRREE FO NIAGHTEY (the sheep under snow) (song frag.)}

Texts: manuscript texts: MNHL unacc. for Harrison (1869: 127) from a manuscript of John Crellin (1764-1816) of Orrisdale MI, and Harrison (1873: 176); Clague Bk 5: 48 1st stanza plus refrain only, MK/M72; 1st., M73; 1st.) (1905) MNHL MS 09495 (Box. 6).

Printed texts: Peacock (1863: 64-65); Broadside c. 1870 by J. C. Faragher, Douglas (MNHL H140 Manx Language Scrapbook); Moore (1896: 187 from Harrison 1869 \& 1873, all having 8 stanzas plus refrain).

Tune: MNHL MS unacc. for Harrison (1869: 126) from a ms. of John Crellin, Orrisdale MI; Clague C3/36: 1 Mary Gawne [Peel]; C4/30: 1 Mylrea; JFSS VII/28: 117-120; Mona Douglas MS 7 [10] John Matt Mylechreest, Thalloo Hogg LO, 1929.

Printed sources: Barrow (1820: 22); Moore (1896: from Harrison 1869 from ms. of John Crellin, Orrisdale MI); Kennedy (1975: 190, 199 from Mona Douglas MS Coll.).

The song is about the loss of a substantial number of sheep in deep snow on the mountains above Lonan parish by Nicholas Qualtrough of Raby LO c. 17001705. As with Mylecharaine (above), this became one of the most renowned traditional songs in the Manx repertoire. For a discussion and analysis of the song see Broderick (1984b).

NY KIRREE FO NIAGHTEY (song frag.).

Thomas Vondy (1811-1896), Ramsey, Lezayre, 18 April 1891 (Rhŷs 6/143-144). 
[refrain]

iri fu boylən

đə yəl ðəðə $\mathrm{Xl}^{\prime} \mathrm{iu}$

th $^{\text {ha }} \mathrm{n}$ kiri fo $\int \mathrm{njãx} \mathrm{t}^{\text {th }}$

xa dəuən as vəd ru
Irree shiu bochillyn

dy gholl dys y chlieau

ta yn kirree fo sniaghtey

cha dowin as va'd rieau.

[Arise, boys, / to go to the mountain, / the sheep are under snow / as deep as they ever were].

NY KIRREE FO NIAGHTEY (song frag.).

John Skillicorn (1820-1893), Ballagare, Lonan, 21 April 1891 (Rhŷs 6/154).

'Kirree fo Niaghtey [kıri fo n'jæ:xt $9 \mathrm{i}]$ JSk "sheep under the snow" (folksong) (it was [a] genuine Kk. Lonan song and the hero of it was a real Lonan man; he was called [kpltfərax re:bi] [Qualtrough Raby]. Ræ̋bi [re:bi] is a place there) ${ }^{56}$ (Rhŷs $6 / 154)$.

[refrain]

iri zu giljən / boixən Irree shiu guillyn/boyaghyn

as gəu Ju ðəðən kliu as gow shiu dys yn clieau

$\theta$ a n kıri fo n'jaxt $\theta \mathrm{i}$ ta yn kirree fo niaghtey

ha d $\mathrm{d}^{\text {houn }}$ as vəd $\mathrm{riu}^{57} \quad$ cha dowin as v'ad rieau.

[Arise ye boys/shepherds / and go to the mountain / the sheep are under the snow / as deep as they ever were].

NY KIRREE FO NIAGHTEY (song frag.).

Mrs. Margaret Caine (1810-1894), ${ }^{58}$ Ramsey, Maughold, 11 August 1892 (Rhŷs 6/176).

[refrain]

i:ri fu bo:xel'on

gəu fu ðən (sic) kl'iu

ta n kiri fo n'æ:xtə

as (sic) ð’un' as vəð riu
Irree shiu bochillyn

gow shiu da'n clieau

ta yn kirree fo niaghtey

as (cha) dowin as vad rieau.

[Arise ye, shepherds, / go ye to the mountain / the sheep are under snow / as deep as they ever were].

56 Raby is situated just north-west of Laxey on a spur overlooking Laxey Glen (at SC4285). It means 'boundary farm' (Sc rá-by') and adjoins the boundary between the treen of Alia Colby (in which it is situated) and that of Colby (PNIM/IV: 345).

57 For differing variants and a discussion of the song Ny Kirree fo Niaghtey, see Broderick: $1984 \mathrm{c}$.

58 'She has heard it sung, but she remembers no more of it though there was a great deal' (Rhŷs 6/176). 
NY KIRREE FO NIAGHTEY (song frag.).

John Nelson (1839-1910), Ramsey, 8 August 1909 (V/1094; HLSM/I: 320-323).

I

lö:rg 'gjeurə de 'nja:xtə

as 'arax ðə 'rio:

va nə fan: kiri 'maru:

as no 'i.dn ve:yə 'bijo:

[refrain]

o: i:ri Ju gil'i[ən]

as 'ga-u: Ju dan 'kl'u:

ta nə kiri fo njaxtə

ho daudn əs vad 'ru:

II

'fp: duət nik 're:bi

as 'e:i nə la:i tin

ta nə kiri fo njaxti

ซns 'bre:id fa're:nə fin

III

kiri to ' $\varepsilon$ :m ons nən 'l'a:yən

as 'go:ir sə kl'u: rəi:

kiri kö:i kp:n nə 'ki:ft'ə

nax 'dzig ðə bræx 'va-i

IV

ta 'molt $\varepsilon: m$ sonən 'olik

as 'dzi:s son ə ke: $1 \mathrm{ft}$

as 'ga nə tri: 'elə

son ə tre: joms 'be:s
Lurg geurey dy niaghtey

as arragh dy rio

va ny shenn kirree marroo

as ny eayin veggey bio

O irree shiu. guilley (yn)

as gow shiu da'n clieau

Ta ny kirree fo niaghtey

cha dowin as v'ad rieau

Shoh dooyrt Nick Raby

as eh ny lhie çhing

Ta ny kirree fo niaghtey

ayns Braaid Farrane Fing

Kirree ta aym ayns nyn Ihargan

as goair sy Clieau Ruy

Kirree keoi Coan ny Kishtey

nagh jig dy bragh veih

Ta mohlt aym son y Nollick

as jees son y Caisht

as gaa ny tree elley

son y traa yiowm's baase.

[1. After a winter of snow / and a spring of frost / the old sheep were dead / and the little lambs alive.

[Refrain]: O rise up, lad(s) / and go to the mountain / The sheep are under snow / as deep as they ever were.

2. This is what Nick Raby said as he lay sick / The sheep are under snow / in Braaid Farrane Fing. ${ }^{59}$

3. I have sheep in our lhargan ${ }^{60} /$ and goats in Slieau Ruy ${ }^{61} /$ wild sheep in Coan ny Kishtey ${ }^{62}$

4. I have a wether for Christmas / and two for Easter / and two or three others / for the time I shall die].

59 A small stream on the eastern side of Snaefell at the present Les Graham memorial shelter (SC398875).

60 'steep hill slope' (ScG leargan). For the distribution of this element see PNIM/VII: Index of Place-Name Elements s.v. lhargan.

61 'red mountain', above Laxey (SC442873).

62 'hollow of the chest'. A large chest-like stone in the upper part of Cornaa Glen (c. SC424888). 
NY KIRREE FO NIAGHTEY (song frag.).

Harry Kelly (1832-1935), Cregneash, Rushen, 28 January 1933 (M/Cyl. 24 (lines 1-2), M/III: 1874).

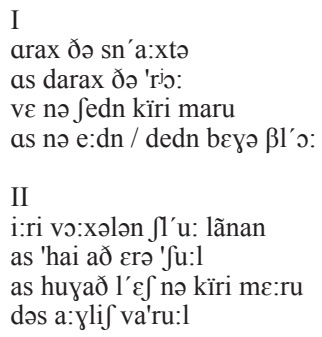

[1. A spring of snow / and a spell of frost / the old sheep were dead / and the little lambs alive.

2. Arise, shepherds of Slieau Lonan ${ }^{63} /$ and they went over (Cronk y) Çhooyl ${ }^{64} /$ and they brought the sheep with them / to the armpit of Barrule $\left.{ }^{65}\right]$.

\section{$2.26 \mathrm{OH}$, SOIEYM SEOSE SYN UINNAG (Oh, l'll sit up in the window) (song frag.) Text: No other text known. \\ Tune: No tune known.}

OH, SOIEYM SEOSE SYN UINNAG (song frag.)

Harry Kelly (1852-1935), Cregneash, Rushen, 28 January 1933 (MIII: 1929; HLSM/I: 332-333).

o: seiəm 'so:s sən 'ünjag as ke:n'əm le: as 'i: as ' $\int \varepsilon d n$ ə bo:1 njim 'dəßəront (sic) sa:n gre:i mĩ:n mə 'xri:

\author{
Oh, soieym seose syn uinnag \\ as keaynym laa as oie \\ as shen y boayl neeym dobberan \\ son graih meen my chree.
}

[Oh, I shall sit up in the window / and I shall weep day and night / and that is the place I shall lament / for the dear love of my heart].

63 'Lonan mountain', i.e. the group of the three mountains Slieau Lhean ('broad mountain', G sliabh + leathan), Slieau Ouyr ('dun-coloured', G odhar), Slieau Ruy ('red/brown', G obl. ruaidh) to the north of Laxey.

64 There was a farm just below Laxey Wheel known as Cronk y Chooyl (SC432852) 'hill of the walking' ( $\mathrm{G}$ cnoc a' t-siubhail), i.e. a gathering place for shepherds as they went (walked) on to the mountain (cf. PNIM/IV: 291). Or it could be er y çhooyl 'immediately, at once' (G. ar an tsiubhal).

65 Probably Laggan Varool (SC435902). 


\subsection{OLLICK GHENNAL (Happy Christmas) (chant)}

Text: Kelly (1866) s.v. Qualtagh notes the following:

the first person or creature one meets going from home. This person is of great consequence to the superstitious, particularly to women the first time they go out after lying-in.

Cregeen (1835) s.v. Qua(a)ltagh 'one who meets' ${ }^{66}$ (10 li.). Otherwise known as 'first foot', Cregeen (1835: s.v. Quaaltagh) notes:

The first person met on New Year's Day, or on going on some new works, \&c. A company of young lads or men, generally went in old times on what they termed the Qualtagh, at Christmas or New Year's Day to the house of their more wealthy neighbours; some one of the company repeating in an audible voice the following rhyme.

Moore (1891: 102-103; 10 li. with Eng. trans.). Moore (ibid.) has this to say about the occasion:

January 1, New Year's Day [...] was the occasion for various superstitions [...]. Among these was the 'first foot'. The 'first foot', called the qualtagh in Manx [G cómhdháil + tach][...]. The qualtagh (he or she) may also be the first person who enters a house on New Year's morning. In this case it is usual to place before him or her the best fare the family can afford. It was considered fortunate if the qualtagh were a person (a man being preferred to a woman), of dark complexion, as meeting a person of light complexion at this time, especially if his or her hair is red, would be thought very unlucky [...]. If the qualtagh were spaagagh [ScG spàgach], or splay-footed, it would be considered very unfortunate. It was important, too, that the qualtagh on New Year's Day should bring some gift, ${ }^{67}$ as if he or she came empty-handed, misfortune would be sure to ensue. To meet a cat first on this day was considered unlucky. It was supposed to be necessary to exercise great care to sweep the floor of the house on New Year's morning from the door towards the hearth, so that the dust should go towards the hearth, for, if this were not done, the good fortune of the family would be considered to be swept from the house for that year. It was formerly the custom for a number of young men to go from house to house on New Year's Day singing the following rhyme (Moore 1891: 102-103). ${ }^{68}$

66 cf. G cómhdháil.

67 Nowadays the visitor brings three items: a piece of coal, a potato, and some salt, to represent fire (warmth), plenty to eat, and good health respectively.

68 The full text, as given by Cregeen (1835: 132), runs as follows: Ollick ghennal erriu as blein feer vie / Seihll as slaynt da'n slane lught-thie / Bea as gennalys eu bio ry-cheilley / Shee as graih eddyr mraane as deiney / Cooid as cowryn, stock as stoyr / Palçhey phuddase as skaddan dy-liooar / Arran as caashey, eeym as roayrt / Baase myr lugh ayns uhllin ny soalt / Cadley sauçhey tra vees shiu ny lhie / As feeackle y jargan, nagh bee dy mie [A merry Christmas to you and a good New Year/Long life and health to the whole household / Life and happiness to you and sprightliness together / Peace and love between women and men / Goods and riches, stock and store / Plenty of potatoes and 
Tune: No tune known.

OLLICK GHENNAL (chant frag.).

Ned Maddrell, Glenchass, Cregneash, Rushen, 18 August 1972 (LSS/902).

olik' 'genal: as 'b'l'e:n no 'va:i

ši:1' əs fe: dan 'sledn lox 'ta:i aran əz 'kę:зz 'i:bm əz rŏṛt

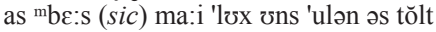
fi: əs fe: tre: 'bi: az 'hed' Ju ðə 'la:i as 'fi:klən: nə dza:ıgan na 'bi: ðə 'ma:i
Ollick Gennal as Blein Noa Vie Seihll as fea da'n slane lught-thie Arran as caashey, eeym as roayrt as baase mie lugh ayns uhllin as toalt Shee as fea tra erbee as hed shiu dy lhie as feeacklyn ny jargan, nagh bee dy mie!

[A Happy Christmas and a Good New Year / Life and rest to the whole household / Bread and cheese and butter in abundance / and a good death to the mouse in stackyard and barn / Peace and tranquillity whenever you go to bed / and the fleas' teeth, may they not be good!].

\subsection{PIPE ASTOMBAGEY (pipe and tobacco) (rhyme)}

Text: No other texts known.

Tune: No tune known.

PIPE AS TOMBAGEY (rhyme)

Thomas Christian (1851-1930), Ramsey, July-September 1929 (M/II: 1267; HLSM/I: 212-213).

peip as tomba:gə

as øuni ə'n॰:rn

t $\varepsilon$ 'kør $\varepsilon r$ nə frødlaxən

kre: $\varepsilon r$ mə hod'n'
Pipe as tombagey

as awree yn oarn

T'eh cur er ny fritlagyn

craa er my hoin

[Pipe and tobacco / and soup of barley / it makes the rags / shake on my bottom].

\subsection{ROW OO ECYVARGEY? (were you at the fair?) (rhyme)}

Text: oral versions: John Kneen (The Gaaue) (1859-1958), Ballaugh Curragh, 20 January 1952 (YCG5), Ned Maddrell, Glenchass, Rushen, 18 February 1953 (YCG12).

Tune: No tune known.

ROW OO EC Y MARGEY? (rhyme).

John Kneen (The Gaaue) (1859-1958), Ballaugh Curragh, 20 January 1952 (YCG/5; HLSM/I: 258-259).

herring enough / Bread and cheese, butter and fat / Death like a mouse in a stackyard or barn / Sleeping safely when you are in bed / And the flea's tooth, may it not be good]. 
rau u egə 'me:gə

əs rin u 'fa:gən mənə 'slei

rin u 'fa:gən tom ə 'snje:gə

ma:kax er dribm 'vuk

as hiudn ə fə'snje:g

ma:kax e:r k'ali 'k'a:k

as vad 'gol mə'git ən 'me:gə

dzeən e. $\chi_{1}$ hul'ı rid va fju: 'fa:gən

as va ḑrbm ə 'snje:gən

e:bəl gol no 'spui:

son: vi 'e:bəl getlax herif

ən dri.m ən vuk

fen 'ulju ta mi ə kla: ft' ən ḑe:

\author{
Row oo ec y margey \\ as ren oo fakin monney sleih? \\ Ren oo fakin Tom y Snieggey \\ markagh er dreeym vuck? \\ As Hudn y Finneig \\ markagh er kellagh kiark? \\ As v'ad goll mygeayrt yn margey \\ jeeaghyn er dy chooilley red va feeu fakin \\ as va Jem y Snieggan \\ abyl goll ny s'bieauee \\ son v'eh abyl getlagh harrish \\ yn dreeym yn vuck.
}

Shen ooilley ta mee er clashtyn jeh.

[Were you at the fair / and did you see many people / did you see Tom the Nit / riding on a pig's back / and Juan the Mite / riding on a gander / And they were going about the fair / looking at everything that was worth seeing / and Jem the Ant would be / able to go faster / for he could fly over / the pig's back.

That's all I've heard of it].

ROW SHIU EC Y VARGEY? (rhyme).

Ned Maddrell (1877-1974), Glenchass, Rushen, 18 February 1953 (YCG/12; HLSM/I: 356-357).

\author{
rau Ju eyə va:yə \\ nak fu monə slei

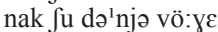 \\ ma:kax keljax 'gœi - na 're: \\ va mi egə va: ${ }^{\mathrm{r}} \gamma$ ə \\ hanık mi ram slei \\ ax ha vak mi d $\varepsilon^{1}$ njə ve:ye \\ ma:kax $\varepsilon$ kaljax gœi
}

\author{
Row shiu ec y vargey \\ naik shiu monney sleih \\ naik shiu deiney veggey \\ markiagh kellagh guiy - nagh re \\ Va mee ec y vargey \\ honnick mee ram sleih \\ Agh cha vaik mee deiney veggey \\ markiagh er kellagh guiy.
}

[Were you at the fair / did you see many people / did you see the little people (fairies) / riding on a gander - isn't it / I was at the fair / I saw many people / but I did not see the little people / riding on a gander].

\subsection{SHANNON REA (smooth Shannon) (song frag.)}

Text: oral text: Harry Kelly, Cregneash RU, 25 January 1933 (M/III: 1931-1932; Cyl. 5).

Manuscript texts: Clague Bk 5: 118, Bk 7: 50-52 ent. 'As I walked out on May Day morn', MTSSF/I: 19-22, J. R. Moore MNHL MS 09495.

Printed texts: Gilchrist (1924-1926: 212-213) 2qq, MTSSF/II: 30. 
Tunes: Clague C1/6: 2 informant not named ent. Shannon Rea (smooth Shannon), C1/13: 1 John Ratcliffe, The Howe RU ent. Moghrey laa Boaldyn (May-Day morning), C1/29: 3 Tom Kermode, Bradda RU ent. Moghrey Laa Boaldyn, C1/30: 1 Tom Kermode, Bradda RU ent. Myr hoill mee magh moghrey Laa Boaldyn (as I walked out on May Day morning), C3/42: 1 John Joughin, The Garey LE ent. Shannon Rea, 'Three times I kissed her ruby lips', Gilchrist (1924-1926: 143-144). Seemingly derived from the broadside ballad 'Shannon Side' (c. 1803) (National Library of Ireland).

SHANNON REA (song frag.).

Harry Kelly (1852-1935), Cregneash, Rushen, 25 January 1933 (M/III: 19311932; Cyl. 5; HLSM/I: 334-335).

tre: hai mij 'ma:x le: 'bo:ldən as 'mp:ri 'fa:id'n' do 'le: nə 'ว:3agən vad 'sĩnal as nə 'be:ldzən ledn də 'vle: red'n' mî mə'de:al ben $\varepsilon: g$ ə bwo:iax a 'na:k mi 'riu nə 'bwo:i ve l'a:yarən (sic) 'eks mar 'ro:zən as 'sul'on gorif 'sme: vei 'be:tal nə 'le:diən as tii:rayən fa:ðə tui də 'smu:n'axtən $\varepsilon r$ 'gra:i mə xri: hüyi 'arəms fil' ə dze: as 'tyodn də 'l'u:r va mi fu:l'mæ:ri gol tru:d on tanal (sic) 're:

\author{
Tra hie mish magh Laa Boaldyn \\ as moghree fine dy laa \\ ny usghagyn v'ad singal \\ as ny biljyn lane dy vlaa \\ Ren mish meeteil ben aeg cha bwaagh \\ cha naik mee rieau ny s'bwaaee \\ Va lieckanyn eck's myr roseyn \\ as sooillyn gollrish smear \\ V'ee beatal ny ladeeyn \\ ass çheeraghyn foddey twoaie \\ Dy smooinaghtyn er graih my chree \\ hug eh orrym's shilley jeir \\ As çhionn dy liooar va mee shooyll mâree \\ goll trooid yn Çhannon Rea.
}

[When I went out on Mayday / it was a fine day's morning / the birds they were singing / and the trees were full of bloom / I met a fine young woman / I never saw one more beautiful / her cheeks were like roses / and her eyes like blackberries / She surpassed the ladies from far northern countries / To think of my heart's love / she made me shed a tear / and close enough I was walking with her / as we went along the smooth Shannon].

\subsection{SHEE AS FEA (peace and rest) (rhyme)}

Text: No other text known.

Tune: No tune known.

SHEE AS FEA (rhyme)

Harry Kelly (1852-1935), Cregneash, Rushen, 28 January 1933 (M/III: 1929; HLSM/I: 332-333). 
fi: as 'fe: as ag'n'a 'ma:i as baidn də 'ja:x nə 'xi:'tən

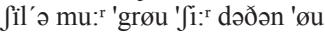
$\int \varepsilon d n$ ə bo:l hwu:r mi 'bedn

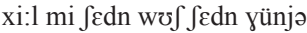

Shee as fea as aigney mie as bine dy yough ny cheartyn Shilley mooar grouw sheear dys yn Owe shen y boayl hooar mee ben.

Cheayll mee shen woish shenn ghooinney.

[Peace and quiet and good will / and a drop of drink on occasion / A great gloomy sight west to the Howe / That's where I found me a wife.

I heard that from an old man].

2.32 SHOOYLL, SHOOYLL, YN DOOINEY BOGHT (Walking, walking, the poor man) (children's rhyme)

Text: No other text known.

Tune: No tune known.

SHOOYLL, SHOOYLL YN DOOINNEY BOGHT (children's rhyme) Ned Maddrell (1877-1974), Glenchass, Rushen, April/May 1948 (IFC/40; HLSM/I: 368-369).

Ju:1 fu:1 ən dən'ə bo:x rœi rœi ən e:rin'px

l'igə l'ig'ə líg'ə dən'ə sc: ${ }^{1} r$
Shooyll, shooyll, yn dooinney boght

roie, roie, yn eirinagh

Ihiggey, Ihiggey, Ihiggey, y dooinney seyr.

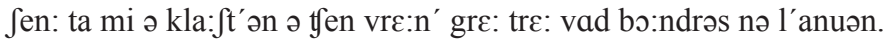

Shen ta mee er clashtyn ny çhenn ${ }^{69}$ vraane gra tra v'ad boandyrys ny lhiannooyn.

[Walking, walking, the poor man / running, running, the farmer / galloping, galloping, galloping, the gentleman.

That's what I heard the old women saying when they'd be nursing the infants].

\subsection{TOM JACK JOHN (rhyme)}

Text: oral versions:

1. Thomas Taggart, Grenaby ML, 27 August 1930 (M/IV: 2312).

2. Edward Kennah, Ronague AR, 27 August 1930 (M/IV: 2533).

3. Tommy Leece, Kerrookeil ML, Christmas/New Year 1950/1951 (Jackson 1955: 136).

4. Mrs. Sage Jane Kinvig, Garey Hollin, Ronague AR, 9 October 1952 (YCG/33).

69 Seemingly a fossilised form of shenn 'old' (G sean (n)) in Rushen parish (cf. HLSM/II: 398 v.s. shenn). 
Tune: No tune known.

TOM JACK JOHN (rhyme).

Thomas Taggart (1846-1933), Grenaby ML 27 August 1930 (M/IV: 2312; HLSM/I: 388-389).

to:m dzek dz̧on ve sïnal mör 'lõn

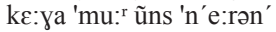
bala ba'ru:l ve tit erə tfu:1 plüyə fa:łt as kl'e:zən
Tom Jack John v'eh singal myr lhon caggey mooar ayns Nherin $^{70}$ Bella Barool va çheet er-y-çhooyl pluckey folt as cleayshyn.

[Tom Jack John, he was singing like a blackbird / of a great war in Ireland /

Bella Barrule came at once / pulling at her hair and ears].

TOM JACK JOHN (rhyme).

Edward Kennah (1860-1938), Ronague, Arbory, 27 August 1930 (M/IV: 2522; HLSM/I: 396-397).

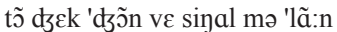
a're:nən hink wif 'ne:rin' as 'bela ba'cu:1 vei tyit crə xu:1 as 're: $\beta$ folt as kle:ion
Tom Jack John v'eh singal myr thon arraneyn haink woish Nherin as Bella Barool v'ee çheet er y chooyl as raipey folt as cleayshyn.

[Tom Jack John, he was singing like a blackbird / songs which came from Ireland / and Bella Barrule she came up behind him / tearing at her hair and ears].

TOM JACK JOHN (rhyme).

Tommy Leece (1860-1956), Kerroomooar, Kerrookeil, Malew, Christmas/New Year 1950-1951 (Jackson 1955: 136).

'A local verse on a half-witted lad who was terrified of the Irish, and hoped that his brother Harry of Barrule would come to rout them' (Jackson 1955: 136).

tom dзæk dзpn ve: sinəl mö. lon də rıu ka:gə vu:r os n' $\varepsilon:$ rən əs hærı ve'ru:1 vi ffit $\varepsilon$ r 1 ffu:1 re:və folt əs kle:ən
Tom Jack John v'eh singal myr lhon dy row caggey vooar ayns Nherin as Harry Varrule ve çheet er-y-çhooyl raipey folt as cleayshyn.

70 The caggey mooar here may refer to the 1798 Irish rebellion against English rule in Ireland in which a small French army also took part (Moody \& Martin 1967: 245). Or to any of the subsequent minor risings: in 1803 (ibid.: 247), in 1848 (ibid.: 262), in 1867 (ibid.: 279). 
[Tom Jack John, he was singing like a blackbird / that there was a great war in Ireland / and that Harry Barrule was coming soon / tearing (at his) hair and ears].

TOM JACK JOHN (rhyme).

Mrs. Sage Jane Kinvig (1869-1962), Garey Hollin, Ronague, Arbory, 9 October 1952 (YCG/33; HLSM/I: 380-381).

tobm dzak dza:n sinal mə la:n

ka:gə mu:r ${ }^{\text {rs n'e:rin' }}$ harə bə'ru:1 tit eri fu:1

re:və folt əs kle: ${ }^{2}$ ən

\author{
Tom Jack John singal myr lhon \\ caggey mooar ayns Nherin \\ Harry Barrule çheet er-y-çhooyl \\ raipey folt as cleayshyn.
}

[Tom Jack John singing like a blackbird / of a great war in Ireland / Harry

Barrule coming at once / tearing (at his) hair and ears].

\subsection{VA YN DOW BUIRROOGH (the ox was bellowing) (rhyme)}

Text: No other text known.

Tune: No tune known.

VA YN DOW BUIRROOGH (Rhyme)

Thomas Christian (1851-1930), Ramsey, July-September 1929 (M/II: 1412; HLSM/I: 226-227).

\author{
ve ən døu ba'ru:x \\ ve $\varepsilon d$ beg $\varepsilon \mathrm{r}$ də kəpər \\ as ve bre:gən 'mu: ${ }^{\mathrm{r}} \mathrm{d} ə \mathrm{ja}:{ }^{\mathrm{r}} \mathrm{n}$ \\ tre: vi fe:dzə cr nə 'beləsən \\ vi $\varepsilon \int$ ba'ru:x mor 'ka: ${ }^{r n}$
}

\author{
Va yn dow buirroogh \\ va edd beg er dy copper \\ as va braagyn mooar dy yiarn \\ traa v'eh sheidey er ny bellyssyn \\ v'eh eisht buirroogh myr cayrn.
}

[The ox was bellowing / there was a wee hat on it of copper / and large shoes of iron / When it was blowing on the bellows it was then roaring (bellowing) like a trumpet].

\subsection{V'EH DOOINEY VEIH BALLAHOWIN (he was a man from Ballahowin) (rhyme)}

Text: No other text known.

Tune: No tune known.

V'EH DOOINEY VEIH BALLAHOWIN (rhyme).

Thomas Christian (1851-1930), Ramsey, July-September 1929 (M/II: 1397; HLSM/I: 224-225). 
vi dũn'ə vei bal'a 'haun' vi ba're:l'e tre: də re: flaun'

as vi ko:r1'ax əð stïl də krck nən 'eirax
V'eh dooinney veih Ballahowin v'eh baarail e traa dy rea shliawin as v'eh coyrlagh ad still dy creck nyn eiraght.

[There was a man from Ballahowin / he was slyly spending his time / and he was advising them still to sell their inheritance].

2.36 VERMAYD CAABYL DYSYN ANKER (we'll put the cable to the anchor) (song frag.) Text: No other text known.

Tune: No tune known.

VERMAYD CAABYL DYS YN ANKER (song. frag.)

Harry Kelly (1852-1935), Cregneash, Rushen, 28 January 1933 (M/Cyl. 6; HLSM/I: 336-337).

ve maid' ke:bal dəðə nạkə

as 'rïgən dəðə 'xrodn

g'il' on ' $\varepsilon$ :gə dusnə $\int \mathrm{s}:$ ltiən

spn te ən gyi: wu:r ' 'fe:dza 'tfodn

\author{
Vermayd caabyl dys yn anker \\ as rigging dys $y$ chroan \\ guillyn aegey dys ny shiaulteeyn \\ son ta yn geay wooar sheidey çhionn.
}

[We shall put a cable to the anchor / and rigging to the mast / young lads to the sails / for the great wind is blowing hard].

\subsection{YN GRAIHDER JOUYLAGH (the demon lover) (song frag.)}

Text: Oral version: Mrs. Sage Jane Kinvig, Garey Hollin, Ronague AR, 9 October 1952 (YCG/32).

Manuscript version: MK/M34, 2st.), (38; 21/2st.) (1905) MNHL MS 09495 (Box 6). Printed versions: Moore (1896: 118 John Quayle, Glen Maye PA).

Giving the various titles as 'A warning for married women', 'Demon/Daemon lover', 'House carpenter', 'James Harris/Harries', David Speers (2016: 54 s.v. 'Banks of Italy') notes that the original version of the song (in English) was seemingly written in 1657 by a certain Laurence Price, though Yn Graihder Jouylagh seems to derive from 'The Daemon Lover or House Carpenter' (c. 1860). Speers adds (2016: 54):

$[\mathrm{M}]$ any variations have evolved but the basic story is of a woman pledged to her lover, who goes away to sea. When he returns after seven years as a ghost to make good the marriage vows, she says she is married (sometimes to a house carpenter). The ghost or demon tries to persuade her to leave and sail away with him (and he will take her to where 'the white lilies grow on the banks of Italy'). She goes with him but after less than three days, she regrets having left, and when he hears this he breaks the masts and sinks the ship (Speers 2016: 54). 
Tune: Clague C4/24: 8 John Quayle, Gordon PA, G/105: 4 ent. Moore (1896: 233 John Quayle, Glen Maye PA ent. Yn Graihder Jouylagh (the demon lover). Both manuscript versions of the tune have the word '?Manx' to the side; G/105: 4 also has 'Demon Lover' pencilled in brackets. Gilchrist (JFSS VII/28: xv) notes this as one of those four songs that are a Manx version of the English original (cf. Moore 1896: 118; 7st. from John Quayle, Glen Maye PA (oral), Cashen 1912: 70).

YN GRAIHDER JOUYLAGH (song frag.).

Mrs. Sage Jane Kinvig (1869-1962), Garey Hollin, Ronague, Arbory, 9 October 1952. Recited. (YCG/32; HLSM/I: 380-381).

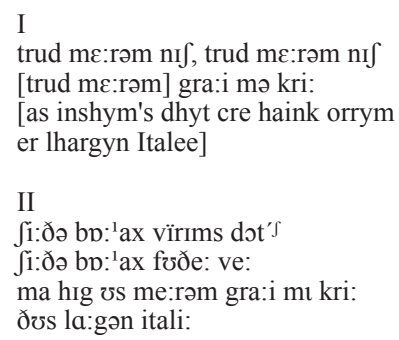

\author{
Trooid mârym nish, trooid mârym nish \\ trooid mârym, graih my cree \\ [as inshym's dhyt cre haink orrym \\ er Ihargyn Italee].
}

\begin{abstract}
Sheeidey bwaagh verrym's dhyt sheeidey bwaagh fod eh ve my hig uss mârym, graih my cree dys Ihargyn Italee.
\end{abstract}
Braagyn bwaagh vermayd's dhyt braagyn ta airh ta bwee
my hig uss mârym, graih my cree dys Ihargyn Italee.

[1. Come with me now, come with me now / (come with me) love of my heart / (and I'll tell you what came upon me on the banks of Italy).

2. Fine silk I will give to you / fine silk it can be / if you come with me, love of my heart / to the banks of Italy.

3. Fine shoes we'll give to you / shoes of yellow gold / if you come with me, love of my heart / to the banks of Italy].

\subsection{YN MAARLIAGH MOOAR (the big thief) (song frag.) ) $^{71}$}

Text: oral version: Mrs. Margaret Caine, Ramsey, 11 August 1892 (Rhŷs 6/176). Printed version: in Moore (1896: 214, 1 st., from Rhŷs). Regarding the contents of the song, Moore (ibid. xxix) comments: '[it] appears to convey the moral that evil is easily learned.'

Tune: No tune known.

71 Moore (1896: 214) prints the song in his Manx Ballads under the title Yn Maarliagh Mooar 'the big robber', acknowledging that he had received it from Rhŷs (Moore 1896:

$\mathrm{xxx}$ ), but with 'corrected' text. 
YN MAARLIAGH MOOAR (song frag.).

Mrs. Margaret Caine (1810-1894), Ramsey, Maughold, 11 August 1892 (Rhŷs 6/176).

'Aug. 11 Thursday I called on Mrs. Caine in the Mooragh Park: she is a native of Ramsey but was brought up in Maughold [...]. She gave me the beginning of some kind of ballad but she thinks there never was any music of it' (Rhŷs 6/176):

ma:rl'ax wũər va har sə kl'iu jarax ə rif mak re:gel' hygə (ə) vak đə fu:l’ nə đeən rof vi ə e:bəl həogə $n$ fo:gə erə jylin as nə lərg nə Le:u

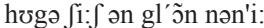
as huər ə $\mathrm{n}$ ræ: $\mathrm{d}$ đə bræu

\author{
Maarliagh wooar va har sy clieau \\ yiarragh eh rish mac Regel \\ hug eh e vac dy shooyl ny dhieyn \\ roish va eh abyl \\ hug eh yn phoagey er e yeaylin \\ as ny lurg ny laue \\ hug eh sheese yn glion ayn(s) yn oie \\ as hooar eh yn raad dy braew.
}

[the big thief was over on the mountain / he would call him Mac Regel / he put his son to walking the houses (i.e. go begging) / before he was able / he put the bag on his shoulder / and the stick in his hand / he sent him down the glen in the night / and he found the way bravely].

\section{How were Manx songs sung traditionally?}

Although we do not possess any sound-recordings ${ }^{72}$ of any Manx traditional songs at all, indicating how they may have been sung, we are fortunate in having two examples of written and one of oral evidence from various sources which we may find helpful:

1. From a descendant of a Manx émigré to the USA in 1827, made in 1845.

2. From one of the collectors of Manx traditional songs, W. H. Gill, made in 1898.

3. From two old ladies from Peel in 1977 who had attended several carval singing sessions in the Methodist chapels during the 1920s/1930s.

72 A number of cylinder sound-recordings were made 1905-1909 (perhaps to 1913) by Yn Çheshaght Ghailckagh of native Manx speech and of some traditional Manx songs from Manx native speakers. Regrettably only four have survived, none containing any song material (Miller 2014: 1-9). 


\section{I Diary of a Manx émigré to the USA in 1827, written in 1845}

The first piece of evidence cited derives from a pseudo-diary seemingly derived from the actual diary ${ }^{73}$ of Thomas Kelly, Sr. and his family of Doolough, Jurby, and their emigration to Ohio USA in $1827 .{ }^{74}$ The pseudo-diary was apparently made by a Mrs. Mary Kelly Ames Denney, a descendant of Thomas Kelly, Jr. and his wife Jane Boyd Kelly, in which under the year 1845 (West 1965: 46) she comments as follows:

[...] How they rush around, these Americans, afraid they will die before they can finish what they have begun [...]. They try to save time but what do they do with that Time when they have it Saved? I thought it would be a Comfort in this strange Land to sing with them the Songs of Zion, but when I had put in all the Quavers and hemi-semi-demi Quavers we loved at home, I was singing alone. The rest of the Congregation had no time for anything Extra (West 1965: 46).

Although appearing in the pseudo-diary, the quote would need to refer to something that actually took place in order for it to be credible. If so, the foregoing suggests that back home in Jurby they used quite some ornamentation in the delivery of whatever they were singing in church/chapel, whether it be ordinary hymns or carvals, ${ }^{75}$ seemingly the latter. For this see $\S 3.3$ below.

\subsection{Evidence of W. H. Gill, a collector of Manx traditional songs, given in 1898}

The second piece of written evidence derives from W. H. Gill in his 'Manx Music: A Sketch', a short treatise on Manx traditional music as an Introduction to his Manx National Music (1898: v-x). Concerning the tunes Gill (1898: viii-ix) writes:

To estimate truly the intrinsic value of these melodies, especially the more ancient ones, one ought in strictness to see them as we found them [...], bare naked melodies, without harmony or accompaniment of any kind [...], without polish or setting. Moreover, to appreciate their full flavour, one ought to come upon them in their original wild state, [...]. They should be heard sung to Manx words and with the vocal intonation peculiar to the people [...]. It is delightful to hear these old men expatiate upon the superior strength and beauty of their

73 For details and a transcript of the actual diary, see Broderick: 2001.

74 Thomas Kelly, Sr. and family emigrated from Doolough, Jurby, in 1827 to Ohio, USA, cf. Isle of Man Examiner 4/11/18/25 October 1935. In the actual diary the son Thomas Kelly, Jr. mentions the death of his father Thomas Kelly, Sr. as taking place on 5 January 1828, aged 67, and buried two days later in Painsville 'Burying Ground', Ohio (Diary [38]). The last entry of the Diary (p. [38]) finishes with the shifting from Painsville to a farm recently purchased just north of Concord Township, Ohio. The pseudo-diary, written to serve the viewpoint that Manxmen left their native home reluctantly (which was clearly not the case with Thomas Kelly, Sr. and his family), continues to 1845 . It is in this latter section that the above quote is to be found.

75 For these, see Moore: 1891. The carvals were sung traditionally on Oie'll Voirrey /i:1 'veri/ (G *oidhche'll bheiridh) 'Eve of the Nativity', 24 December, earlier in the churches, later on in the Methodist chapels. 
ancient language as compared with English - for they know both languages, and are keenly critical. At the end of a verse or a line they will suddenly stop singing and lose themselves in an ecstasy of admiration, commenting upon what they have been singing about, translating a Manx word here and there, explaining an idiom, or enlarging upon the incidents of the story [...] (Gill 1898: viii-ix).

Concerning the singers themselves and their songs Gill (1898: ix) notes:

In the singing of these old people, as well as in their recitation of poetry, of which latter they are particularly fond, we found at times almost a total absence of a definite metrical accent, and in its stead an ever smoothly-flowing rhythm, relieved here and there - often in the least expected places-by a pause of indefinite length. In fact such was the freedom of the 'phrasing' [Gill's quotation marks here and elsewhere], and to such an extent was the rhythmic structure concealed, that much of their music might be appropriately represented like 'plain song' without any bar-lines. Nor was this vagueness due to any lack of rhythmic sense on the part of the performer, for when a dance tune had to be sung it was rendered with due precision and clearness of accent. And yet, if the tunes could be written down, as with a phonograph, exactly as we heard them, and then reproduced faithfully, with all their vagueness of tempo [Gill's italics here and elsewhere], their uncertainness of intonation, their little quaverings and embellishments, quite unrepresentable by ordinary musical notation, if we had all these things faithfully registered, who would care for the result? Some would ask, 'Can these dry bones live?' Others would impatiently exclaim, 'How different from the singing of trained singers!' [...] (Gill 1898: ix).

With regard to the practicalities of noting the tunes Gill (1898: ix) outlines two 'practical difficulties', as he put it: The first only is given here as being relevant to the matter in hand:

[...]. First, as regards the raw material, the object was to obtain an absolutely true record of the melody [...] and in attaining this object the difficulty was two-fold, viz. to represent in the precise and inelastic terms of musical notation, without prejudice and uninfluenced by preconceived ideas of artistic right and wrong, the melody which, as actually heard, was often exceedingly vague and indefinite as regards both tune and time. In respect of intonation, the difficulty lay in discriminating between the peculiar tonality of the ancient 'modes' and that of modern music; while as regards time, the difficulty was the right placing of the bar-lines with due regard to the grammatical accent as distinguished from the artistic pause and emphasis imported by the individual singer (Gill 1898: ix).

As a trained Classical musician, Gill was clearly confronted with material that was difficult or nigh impossible to interpret in traditional 'Classical' staff-notation, particularly in producing on paper an accurate rendering of the vagaries of the melody, often modal in delivery, as produced by the singer. ${ }^{76}$ The fact that such

76 A developed methodology as used today by ethnomusicologists for such material can be seen in Percy Grainger (1908), also in Tocher (1971-2009), a monthly cultural 
difficulties were experienced at all would put the rendition of Manx material, as with the Lincolnshire material noted by Percy Grainger (qv.), in a traditional music setting. ${ }^{77}$

\subsection{Evidence from two old ladies from Peel in 1977 who had attended Oie'll Voirrey services during the 1920s/1930s}

The third piece of evidence, oral in form, was collected in 1977 when Brian Stowell and myself interviewed two old ladies aged c. 75-80 (whose names now escape us) then living in 7 Mona Street, Peel, who, according to them, used to attend carval singing sessions during the 1920s/1930s. Such sessions, they said, would be held on St. Mary's Eve, 24 December, in the Methodist chapel. They said that after a short service the vicar would leave the chapel and the proceedings would be taken over by the clerk. The chapel would be brightly lit with candles and adorned with holly and ivy to give a warm appearance. The clerk would then call for the first carval singer, or singers (sometimes there were two who would sing alternate stanzas). A carval could be short or long, short with around twenty stanzas, long with up to sixty. The average carval would extend to some 35 stanzas or so. The session would last till three or four o'clock in the morning, they said. ${ }^{78}$

We asked them whether the carvals were in Manx or in English. They said in English - at least the sessions they attended, they said. When we asked them how the carvals were actually sung, they had some difficulty in expressing themselves, as it was clear they were not au fait with musical terminology. We then asked them whether they were they sung like ordinary hymns one would sing on a Sunday. They answered with a firm No, stating that there would be 'frills', as they put it, in

magazine of the School of Scottish Studies, University of Edinburgh.

77 Similar comment can also be found in the work of Australian composer and ethnomusicologist Percy Grainger (1882-1961) who recorded a number of traditional Lincolnshire singers at Brigg Fair in May 1908. In his description of English folksong singing styles, set in an end-piece entitled 'English Folk-Songs Sung by Genuine Peasant Folk-Singers', he notes: 'The scales and modes in which most of these tunes are cast are quite different from any that have been employed in art-music for some centuries. And the interpretive traditions [Grainger's italics, also elsewhere] that genuine peasant singers reveal in their performances are hardly less unique. Their rhythmic habits, ornaments, and allotments of syllables to notes have a flavour all of their own, and differ radically from the usages of art-singers; and it is a lack of knowledge of these traditions of folk-song singing that so often makes folksongs ineffective in the mouths of otherwise excellent artists. These records are not folksongs sung at second hand. They are folksongs sung by [...] the very men who have passed such songs down the centuries to us' (Grainger: 1908; Thomson: 1972). For an assessment of Percy Grainger as an ethnomusicologist, see Blacking: 1987.

78 Traditionally, hard dried peas would be thrown by the congregation at poor performance by carval singers. Manx occasions by all accounts could be somewhat exuberant at times, though the two ladies we interviewed said they had not witnessed this tradition. 
the delivery of the tune and that the stanzas would be sung with some irregularity, they said.

If we take all three contributions together, the situation would seem to be as follows:

1. That the delivery of Manx traditional songs and carvals seems to have possessed a degree of ornamentation. It is difficult to say how much, but sufficient at least for it to be commented upon.

2. That there would be irregularity in the singing of each stanza, suggesting that no stanza was rendered the same as any other, that the stanzas were individual in their own right.

3. That the singer would occasionally stop suddenly in mid-song, at the end of a stanza, or of a line in a stanza, in order to explain the background to the text, or add additional information or explain this or that Manx word or idiom, etc.

4. It is clear that Gill makes a difference between trained classical singing and Manx traditional singing, implying that the difference was considerable.

5. The difficulties Gill experienced in noting down the tunes suggest that the singer's voice affected the rendering of the tune, in such a manner as to give an impression to the layman of 'deviation' or 'distortion' in the singer's voice or in the rendition, or that ornamentation of a sort had been employed, etc.

6. The whole would give the impression that Manx traditional songs were rendered in a similar manner to those in other branches of Gaelic tradition in Ireland and in Scotland. ${ }^{79}$

\section{Conclusion}

Though most of the above songs presented are in fragmentary form, they nonetheless give us a good idea of the extent of the song repertoire to be found among the last native Manx Gaelic speakers, recorded as they were between the years 1883 and 1972, as we have seen. However, as we have noted elsewhere (cf. Broderick: 2015, 2017 and 2018a \& 2018b), already in Rhŷs's time, Manx was showing signs of obsolescence (Broderick: forthcoming c), and more so as time went on.

And so with their song repertoire. That is to say that the fragmentary form of their songs would seem to parallel the obsolescence of their Manx.$^{80}$ In principle, the songs in many cases could have been learned fully in early life and subsequently partially forgotten through non-use over time, or that only fragments of them were learned in the first place. Ned Maddrell, for instance, would recite, say, three stanzas of the song Brig Lily and then say, that is all he could remember of it (implying that

79 I personally have witnessed similarities to $\$ 3.1$ in Conamara sean nós singing during the $1970 \mathrm{~s} / 80$ s and to $\$ \S 3.2$ and 3.3 above in Scottish Gaelic traditional singing during the 1970s during my time in Edinburgh.

80 In this regard, see Broderick: 1999. 
he had at one time learned more, if not all, of the song). Nevertheless, the complete mastery of the song Ec ny Fiddleryn by Tom Kermode, Bradda, Rushen, on the other hand, makes clear what was available, and also what was possible. 


\section{Abbreviations}

Manx parish abbreviations

$\begin{array}{lclll}\text { AN - Andreas } & \text { BR - Bride } & \text { JU - Jurby } & \text { MI - Michael } & \text { RU- Rushen } \\ \text { AR - Arbory } & \text { CO - Conchan } & \text { LE - Lezayre } & \text { ML - Malew } & \text { SA - Santan } \\ \text { BA - Ballaugh } & \text { (Onchan) } & \text { LO - Lonan } & \text { MR - Marown } & \\ \text { BN - Braddan } & \text { GE - German } & \text { MA - Maughold } & \text { PA - Patrick }\end{array}$

\section{Other abbreviations}

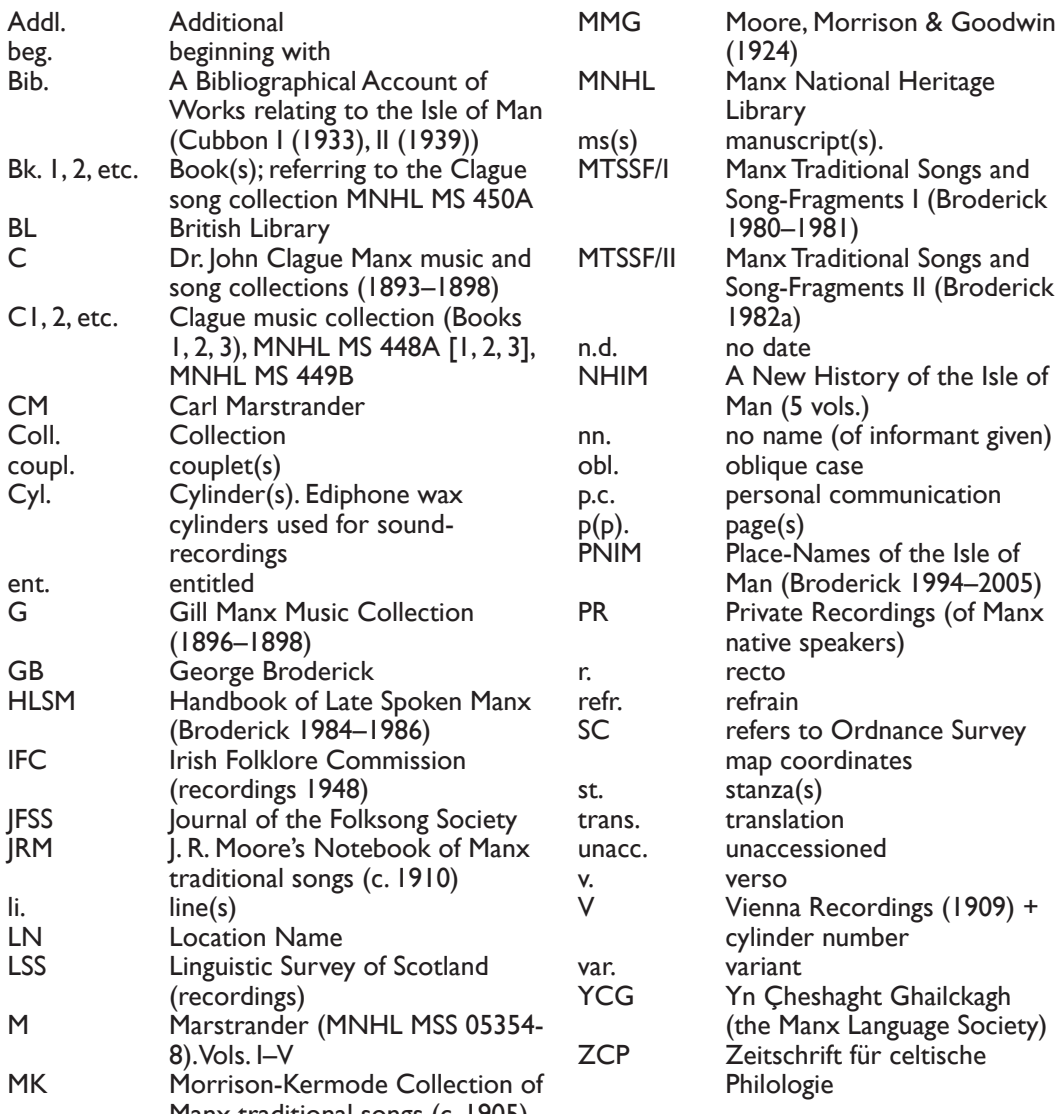




\section{List of References}

\section{Primary Sources}

Clague Collection of Manx Traditional Music. MNHL MSS 448A [1, 2, 3], 449B (Coll. 1893-1898). ${ }^{81}$

Clague Collection of Manx Traditional Songs \& Song-Fragments MNHL MS 450A: Notebooks 1-24. Songs in Bks. 2 (1 item), 3 (3), 4 (1), 5 (39), 7 (1), 9 (1), 10 (27), 12 (6), 16 (33) (Coll. 1893-1898) (MTSSF/II).

Clucas Collection of Manx Traditional Songs \& Song-Fragments MNHL MS 236A. Coll. of George Frederick Clucas (1870-1937) (c. 1900) (MTSSF/I).

Gill Collection of Manx Traditional Music under the title: The Original Collection of Manx Folk Music Made by His Honour the Deemster Gill, Mr. W. H. Gill \& Dr. Clague Completed in 1895 \& 1896 MNHL MS 09702.

Irish Folklore Commission Sound Recordings of Manx Native Speech (22 April-5 May 1948). Recordings digitised for GB in the University of Mannheim, 2011. For transcriptions see HLSM/I: Texts.

J. F. Moore Notebook of Manx Folksong (c. 1910) (in Sophia Morrison Coll.) MNHL MS 09495.

Marstrander Collection of Sound Recordings (Jan./Feb. 1933). For transcriptions see HLSM/I: Texts. Recordings digitised for MNHL in the British Library, 2006, for GB in the University of Mannheim, 2011.

Marstrander Collection: Defunctae Linguae Manniae quae collegit Carolus Marstrander. Four manuscript volumes of Manx material in phonetic script collected in Man 1929, 1930 (MNHL MSS 05354-57 B). A fifth "volume" (box) contains sundry items incl. Dagbok (MNHL MS 05358 B).

Marstrander Dagbok. A diary of Marstrander's field-visits to Man 1929, 1930, 1933 (MNHL MS 05358 B).

Mona Douglas Collection of Manx Music And Songs (1920s) in private hands.

Moore Collection of Manx Traditional Songs (1890s) MNHL MS 00221A. See also Moore: 1896.

Morrison-Kermode Collection of Manx Traditional Songs. The Sophia Morrison and Josephine Kermode Manx Folksong Collection (1905) (Morrison) MNHL MS 5433B/MNHL MS 09495, (Kermode) MNHL MS 08979.

Rhŷs Collection of Native Manx Gaelic Speech Material of His Visits To Man 18861893. Rhŷs's notebooks, eleven in all, of his Manx visits are housed among his papers, the Sir John Rhŷs Papers ([1822]-1953), in the Llyfrgell Genedlaethol Cymru National Library of Wales (NLW), Aberystwyth, Reference-Nr. GB 0210 JORHYS A3/9 (Boxes 60 (Bks. 1-4), $61(5-7), 67(8,9) 62(10,11)$ ). For transcriptions, see Broderick 2015.

Tocher. Tales, songs, traditions, selected from the School of Scottish Studies Archives (1971-2009).

Vienna Recordings. Sound-Recordings of Native Manx Speech (5-9 August 1909). For CDs and accompanying booklet, see Lechleitner \& Remmer (2003). For transcriptions see HLSM/I: Texts.

Yn Çheshaght Ghailckagh Sound Recordings of Manx Native Speakers (30 November

81 For details of an apparent early 1870s start to Clague's collecting Manx traditional music and song material, see Miller 2019 (Manx Notes 151 (2013): 1-6). 
1951-1924 February 1953). Recordings digitised for GB in the University of Mannheim, 2011. For transcriptions see HLSM/I: Texts.

\section{Secondary Sources}

Barrow, J. 1820. The Mona Melodies. A Collection of Ancient And Original Airs of The Isle of Man. London: Mitchell.

Beale, J. 1868. 'Manx Lines on Manx Fairy Steamer', Notes \& Queries (4th series) 2, $368 \mathrm{a}$.

Belchem, J. (ed.) 2000. A New History of the Isle of Man. Vol. V: The Modern Period 1830-1999. Liverpool: Liverpool University Press.

Blacking, J. 1987. 'A Commonsense View of All Music': Reflections on Percy Grainger's Contribution to Ethnomusicology and Music Education. Cambridge: Cambridge University Press.

Bonaparte, L.-L. 1884. 'Initial Mutations in the Living Celtic, Basque, Sardinian, and Italian Dialects'. Transactions of the Philological Society 19 (1882-1884, 1885): $155-202$.

Broderick, G. 1980-1981. 'Manx Traditional Songs and Song-Fragments I' [Clucas Coll.], Béaloideas 48-49, 9-29;

Broderick, G. 1982a. 'Manx Traditional Songs and Song-Fragments II' [Clague Coll.], Béaloideas 50, 1-41.

Broderick, G. 1982b. 'Baase Illiam Dhone'. Celtica 14, 105-123.

Broderick, G. 1984-86. A Handbook of Late Spoken Manx. Tübingen. Niemeyer. 3 vols. Vol. I: Grammar and Texts (with translation), Vol. II. Dictionary, Vol. III: Phonology.

Broderick, G. 1984a. 'Berrey Dhone - a Manx Caillech Bérri?', Zeitschrift für celtische Philologie 40, 193-210.

Broderick, G. 1984b. 'Ec ny Fiddleryn', Zeitschrift für celtische Philologie 40, 211227.

Broderick, G. 1984c. 'Ny Kirree fo Niaghtey', Celtica 16, 157-168.

Broderick, G. 1994-2005. Place-Names of the Isle of Man. Tübingen: Niemeyer, 7 vols.

Broderick, G. 1999. Language Death in the Isle of Man. Tübingen: Niemeyer, Linguistische Arbeiten 395.

Broderick, G. 2001. 'Manx Emigration to the United States of America'. In S. Ureland (ed.), Global Eurolinguistics: European Languages in North America - Migration, Maintenance and Death. Tübingen: Niemeyer, 461-480.

Broderick, G. 2008. 'Mona Douglas and Her songs', Béaloideas 76, 193-247. Updated version 2019. https://www.manxmusic.com/search results.html?q=broderick (accessed 3/3/2020).

Broderick, G. 2015. 'Prof. Sir John Rhŷs and the Manx Gaelic Note-books of His Visits to the Isle of Man (1886-1893)'. https:/www.academia.edu/39797591/John Rhys_A_Pioneer_in_the_Study_of_Manx_draft (accessed 3/3/2020).

Broderick, G. 2017. 'The Last Native Manx Gaelic Speakers. The Final Phase: 'Full' or 'Terminal' in Speech?', Studia Celtica Fennica 14, 18-57.

Broderick, G. 2018a. 'Carl Marstrander's Field Notes from the Isle of Man 1929, 1930, 1933', Celtica 30, 183-205.

Broderick, G. 2018b. 'Prof. John Rhŷs in the Isle of Man (1886-1893): Linguistic Material and Texts'. In R. Karl \& K. Möller (eds.), Proceedings of the Second 
European Symposium in Celtic Studies held at Prifysgol Bangor University from July 31st to August 3rd 2017. Hagen: Curach Bhán Publications, 35-69.

Broderick, G. 2018c. 'Manx Traditional Songs and Song-Fragments in the End-Phase of Manx Gaelic: From the Clague Music Collection (1890s)', Studia Celtica Fennica 15, 28-64. DOI: https://doi.org/10.33353/scf.70414

Broderick, G. 2018d. 'Fin as Oshin - A Reappraisal', Zeitschrift für celtische Philologie 65, 63-81. DOI: https://doi.org/10.1515/zcph-2018-650105

Broderick, G. forthcoming a, 'Manx Traditional Songs and Song-Fragments from the Collections of Sophia Morrison and Josephine Kermode ca. 1904-1909'. Béaloideas.

Broderick, G. forthcoming b, 'Mylecharaine: A Manx Traditional Song Collected from Manx tradition'.

Broderick, G. forthcoming c, 'Prof. John Rhŷs in the Isle of Man (1886-1893): A Linguistic Assessment'.

Cashen, W. 1912. Manx Folklore. S. Morrison (ed.). Douglas: Johnson.

Clague, J. 1911. Manx Reminiscnences. Cooinaghtyn Manninagh. Castletown: Blackwell.

Cookson, E. 1859. Legends of Manxland. Douglas: Quiggin.

Cregeen, A. 1835. A Dictionary of the Manks Language. Douglas: Quiggin.

Cubbon, W. 1933, 1939. A Bibliographical Account of Works Relating to the Isle of Man. Oxford: University Press, 2 vols.

de Búrca, S. 1970. The Irish of Tourmakeady, Co. Mayo. A Phonemic Study. Dublin: Dublin Institute for Advanced Studies.

Douglas, M. 1928. Twelve Manx Folksongs. London: Stainer \& Bell.

Drennan, W. R. 1870. 'Mylecharaine', Notes and Queries, 583-584.

Gilchrist, A. G. 1924-1926: 'Songs and Tunes from the Clague Collection', Journal of the Folksong Society 28-30: 99-327 (no. 28: 99-199; no. 29: 203-280; no. 30: 281-327; Indexes: 329-347).

Gill, W. H. 1896. Manx National Songs. London: Boosey \& Hawkes.

Gill, W. H. 1898. Manx National Music. London: Boosey \& Co.

Grainger, P. 1908. Unto Brigg Fair. Joseph Taylor and Other Traditional Lincolnshire Singers Recorded in 1908 by Percy Grainger. London: Leader Sound Ltd (Leader LEA 4050).

Harrison, W. (ed.) 1869. Mona Miscellany I. Douglas: Manx Society 16.

Harrison, W. (ed.) 1872. An Account of The Loss of the Manx Herring Fleet on the 21st September, 1787, with the Ballads in Manx and English. Douglas: Matthew Glover.

Harrison, W. (ed.) 1873. Mona Miscellany II. Douglas: Manx Society 21.

Holmer, N. M. 1942. The Irish Language in Rathlin Island, Co. Antrim. Dublin: Royal Irish Academy, Todd Lecture Series, Vol. 18. Repr., 2018, London: Forgotten Books.

Holmer, N. M. 1943. The Dialects of Co. Clare. Dublin: Royal Irish Academy, Todd Lecture Series, Vols. 19, 20.

Holmer, N. M. 1957. The Gaelic of Arran. Dublin: Dublin Institute for Advanced Studies.

Holmer, N. M. 1962. The Gaelic of Kintyre. Dublin: Dublin Institute for Advanced Studies.

Jackson, K. H. 1955. Contributions to the Study of Manx Phonology. Edinburgh: Nelson. 
Kelly, J. 1866. Fockleyr Manninagh as Baarlagh. Douglas: Printed for the Manx Society Vol. 8. Manx-Eng. 1-192; Eng.-Manx 197-432. Manx-Eng. portion repr. 1977, Ilkley, Yorkshire: Scolar Press Ltd., under the title Fockleyr Gailckagh as Baarlagh for Yn Çheshaght Ghailckagh.

Kennedy, P. 1975. Folksongs of Britain and Ireland. London: Music Scales Ltd.

Lechleitner, G. \& U. Remmer (eds.) 2003. Tondokumente aus dem Phonogrammarchiv der Österreichischen Akademie der Wissenschaften. Sound Documents from the Phonogrammarchiv of the Austrian Academy of Sciences. The Collections of Rudolf Trebitsch. Celtic Recordings - Ireland, Wales, Brittany, Isle of Man, and Scotland (1907-09). Wien: Verlag der Österreichischen Akademie der Wissenschaften.

Leech, F. n.d. [c. 1861]. Leech's New Illustrated Tourist Guide. Ramsey.

Lhuyd, E. 1707. Archaeologica Britannica. Oxford: The Theater

Mhac an Fhailigh, Éamonn (1968). The Irish of Erris, Co. Mayo. A Phonemic Study. Dublin: Dublin Institute for Advanced Studies.

Miller, S. 2014. "“The Results Are Most Interesting." The Sound Recording Programme of the Manx Language Society', Manx Notes 175, 1-9.

Miller, S. 2017. A. W. Moore: Manx Ballads and Music (1896). A Working Guide. Onchan: Çhiollagh Books. In ten parts: 1. The Sources of the Texts, 2. The Tunes, 3. Correspondence, 4. Working Guide, 5. T. E. Brown's Preface, 6. The Reviews, 7. The Robert Gawne Collection, 8. Personalia, 9. The Oral Texts, 10. The Oral Song Texts. http://www.chiollaghbooks.com/manxnotes/ (accessed 3/3/2020).

Miller, S. 2019. Manx Notes: Folkways and Language (1993-2019). http://www.chiollaghbooks.com/manxnotes/ (accessed 3/3/2020).

Moore, A. W. 1891. The Folk-Lore of the Isle of Man. Douglas: Brown \& Son/London: Nutt. Facsimile repr. 1971, Wakefield: S. R. Publishers 1994, Felinfach: Llanerch Publishers.

Moore, A. W. 1896. Manx Ballads and Music. Douglas: Johnson. Facsimile repr. 1998, Felinfach: Llanerch Publishers.

Moore, A. W., S. Morrison, \& E. Goodwin (eds.) 1924. A Vocabulary of the AngloManx Dialect. London: Oxford University Press.

Moore, A. W. \& J. Rhŷs (eds.) 1893-1894. The Book of Common Prayer in Manx Gaelic, Being Translations Made by Bishop Phillips in 1610, and by the Manx Clergy in 1765. Oxford: Oxford University Press, Manx Society Vols. 32 \& 33.

Ní Bhaoill, Róise 2010. Ulster Gaelic Voices: Bailiúchán Wilhelm Doegen 1931. Béal Feirste: Ultach Trust.

Ó Curnáin, B. 2007. The Irish of Iorras Aithneach County Galway. Dublin: School of Celtic Studies. Dublin Institute for Advanced Studies, 4 vols.

Oftedal, M. 1956. 'The Gaelic of Leurbost, Isle of Lewis', Norsk tidsskrift for sprogvidenskap. Suppl. Bd. IV.

Paton, C. I. 1920. 'Mylecharaine, a Few Notes on an Old Poem', Proceedings of the Isle of Man Natural History and Antiquarian Society 2, 303-309.

Paton, C. I. n.d. [1941]. Manx Calendar Customs. London: The Folklore Society.

Paton, C. I. 1944. "CChengey ny Mayrey" - Samples of Manx Gaelic: 5: Loss of the Fishing Boats at Port St. Mary 1846', Journal of the Manx Museum 70 (5), 131132.

Peacock, W. F. n.d. [c. 1863]. The Manx Table-Book and Keepsake. Manchester: John Heywood.

Quiggin, E. C. 1913. 'Literary Manx and the Language of the Carvals', Mannin 1(1), 35-39. 
Radcliffe, C. 1989. Shining by the Sea. A History of Ramsey 1800-1914. Douglas: Desktop Publishing Service.

Rhŷs, J. 1891. 'Manx Folk-Lore and Superstitions', Folklore 2 (3), 284-313.

Rhŷs, J. 1892. 'Manx Folk-Lore and Superstitions II', Folklore 3 (1), 74-88.

Rhŷs, J. 1895. The Outlines of the Phonology of Manx Gaelic. Published first in Moore \& Rhŷs (1893-1894), then separately in 1895, Oxford: Oxford University Press.

Roeder, K. 1896. 'Folklore of the South of the Isle of Man', Yn Lioar Manninagh 3, 129-190.

Roeder, K. 1904. Manx Notes and Queries. Douglas: Isle of Man Examiner.

Simon, Gerd 2006. 'Chronologie Doegen, Wilhelm. Unter Mitwirkung von Dagny Guhr u. Ulrich Schermaul'. http://homepages.uni-tuebingen.de/gerd.simon/ChrDoegen. pdf (accessed 3/3/2020).

Speers, D. 2016. 'Manx Traditional Ballads: The Broadside Connections Revealed', Béaloideas 84, 42-83.

Stockman, G. \& H. Wagner (eds.) 1965. 'Contributions to a Study of Tyrone Irish: Some Aspects of the Vocabulary, Grammar and Phonology of Tyrone Irish, with Texts', Lochlann 111. Oslo: Universitets-forlaget, LASID point 66.

Strachan, J. 1897. 'A Manx Folksong', Zeitschrift für celtische Philologie 1, 54-58.

Thomson, R. 1972. Joseph Taylor and Other Traditional Lincolnshire Singers Recorded in 1908 by Percy Grainger. High Wycombe: Brier Press, booklet to accompany LP record (Leader LEA 4050 mono).

Thomson, R. L. 1961. 'McLagan Manuscript 180', Scottish Gaelic Studies 9 (1), 9-22. Thomson, R. L. 1979. Bible Chasherick yn Lught-Thie: The Manx Family Bible Introduction. Onchan: Shearwater Press.

Wagner, H. 1959. Gaeilge Theilinn: Foghraidheacht, Gramadach, Téacsanna. Baile Átha Cliath: Institiúid Árd-Léinn Bhaile Átha Cliath.

West, M. \& M. Douglas 1965. Thomas Kelly and Family's Journal in the Year 1827. Douglas: Times Press.

Wood, G. W. 1884. 'George Borrow and the Mylecharane Ballad', Yn Lioar Manninagh 1 (1), 359ff. 